\title{
Aerosol Emissions from Long-lasting Smoldering of Boreal Peatlands: Chemical Composition, Markers, and Microstructure
}

\author{
Olga B. Popovicheva ${ }^{1^{*}}$, Guenter Engling ${ }^{2_{+}}$, I-Ting Ku ${ }^{3,4}$, Mikhail A. Timofeev ${ }^{1}$, \\ Natalia K. Shonija ${ }^{1}$ \\ ${ }^{1}$ Institute of Nuclear Physics, Moscow State University, 119991 Moscow, Russia \\ ${ }^{2}$ Division of Atmospheric Sciences, Desert Research Institute, Reno, NV 89512, USA \\ ${ }^{3}$ Department of Biomedical Engineering and Environmental Sciences, National Tsing Hua University, Hsinchu 30013 , \\ Taiwan \\ ${ }^{4}$ Department of Atmospheric Science, Colorado State University, Fort Collins, CO 80523, USA
}

\begin{abstract}
As large-scale peat burning emissions can severely impact the environment and human health, it is crucial to assess the characteristics of smoke aerosol at the source and at down-wind locations. From March until late summer in 2014, the Tver region, north of the city of Moscow, was considerably affected by long-lasting peat bog fires. Peat bog smoldering emissions from three types of smoke (underground, inside grass, and above grass) were analyzed by an extensive suite of instrumentation that sampled and measured their optical and chemical properties. The particle composition was characterized by organic species with high OC/EC ratios (10-20), with water-soluble organic carbon (WSOC) and levoglucosan (Lev) comprising the largest fraction, up to 30 and $9 \%$, respectively, of the OC. Aliphatic, aromatic, carbonyl, and carboxylate functionalities in the underground smoke were enriched by nitro compounds, and brown carbon (BrC) was identified by a high Absorption Angstrom Exponent (AAE) of 4.1. Organic "tar balls" in the peat smoke were more abundant $(78.5 \%)$ than individual Ca-rich (e.g., Ca-oxides or carbonates), Fe-rich (e.g., Fe-oxides), and Al-rich (e.g., alumosilicates) particles. Peat smoke plumes affected an urban site in Moscow in August 2014, with ambient PM $_{10}$ mass loadings reaching up to $97 \mu \mathrm{g} \mathrm{m}^{-3}$ and $\mathrm{OC}$, EC, and ionic species accounting for a large percentage of the total aerosol enhancement. With the transport of air masses from the peat bog region to Moscow, the OC/EC ratio and AAE reached peak values of 7 and 1.3, respectively. Levoglucosan served as a molecular marker of the impact of peat smoldering, approaching a maximum ambient concentration of $108 \mathrm{ng} \mathrm{m}^{-3}$. WSOC correlated well with Lev, indicating secondary organic aerosol (SOA) formation associated with peat burning emissions. Spectral absorbance features showed characteristics similar to peat burning and traffic source emissions during fire and non-fire related days, confirming the potential effect of transported peat smoke on air quality in megacities.
\end{abstract}

Keywords: Peat bog fires; Biomass burning; Chemical marker; Organic carbon; Functionalities.

\section{INTRODUCTION}

Boreal ecosystems store a large amount of carbon, about one-fifth to one-third of the terrestrial organic carbon, in peat bogs that is partly released into the atmosphere during frequent fires, and consequently renders peatlands as an important source of hazardous smoke (Levine, 1999;

\footnotetext{
${ }^{\dagger}$ Now at California Air Resources Board, El Monte, CA, USA

* Corresponding authors.

E-mail address: polga@mics.msu.su (O.B. Popovicheva); guenterengling@gmail.com (G. Engling)
}

Langmann and Graf, 2003), which considerably affects ecosystems and carbon cycling (Turetsky et al., 2015). Climate change results in drying and reduced water content in peat lands, which in turn causes higher frequency and intensity of peat fires. While peat fires in tropical regions have received the largest attention by both the general public and scientific community (Langmann and Heil, 2004; Gaveau et al., 2014), the largest peat deposits are found in the northern hemisphere (Sheng et al., 2004).

In Siberia, four million hectares of peatlands were burned on average each year between 1975 and 2005, with the fire frequency doubling since the 1990s (Sheng et al., 2004). Intensive peat fires in regions of high population, such as the European part of Russia, affect the air quality in large cities. During the peat bog burning event in 2002 a significant weakening of solar radiation was observed in 
the megacity Moscow, when the visibility dropped to 50300 meters (Chubarova et al., 2011). The extreme smoke event in Moscow during summer of 2010 was another example, demonstrating the strong impact of large-scale peat and forest wildfires on down-wind regions (Popovicheva et al., 2014). Smoke advected from burning peatlands pervaded Moscow city for several weeks, leading to a doubling of the natural mortality rate (Barriopedro et al., 2011).

Physico-chemical characteristics of biomass burning aerosols are highly variable, depending on fuel type (Alves et al., 2010) and combustion phase (flaming or smoldering) (Popovicheva et al., 2015c; Kalogridis et al., 2018). In forest fire emissions, the carbonaceous fraction constitutes $50-70 \%$ of the total PM mass, while inorganic constituents comprise about 15\% (Reid et al., 2005). Organic aerosol particles generated by biomass burning consist mainly of decomposition and pyrolysis products of the biopolymers lignin, cellulose and hemicellulose, characterized by various polar, functional groups. The main examples of these compounds are substituted phenols from lignin pyrolysis, such as guaiacols and syringols, and anhydrosaccharides from cellulose/hemicellulose pyrolysis (Shafizadeh and Fu, 1973; Shafizadeh et al., 1979). The latter ones (levoglucosan and its stereoisomer mannosan and galactosan) have been identified and used extensively as molecular markers for biomass burning emissions (Simoneit et al., 1999).

Once released into the atmosphere, smoke particles undergo physico-chemical processes in the plume that can alter their properties. Specifically, secondary organic aerosol (SOA) formation can occur, especially when solar radiation induces photochemical reactions (Popovicheva et al., 2014; Reid et al., 2005; Tiitta et al., 2016). These modifications of the smoke particle properties can change the direct and indirect climate effects of biomass burning emissions, affecting single scattering albedo and hygroscopicity. Largescale peat and forest wildfires could affect chemical and physical aerosol properties and thus air quality in areas far downwind upon long-range transport of smoke aerosols (Agarwal et al., 2010; Diapouli et al., 2014).

Peat is a heterogeneous mixture of partially decomposed plant material which has accumulated in water-saturated environments in the absence of oxygen (Zaccone et al., 2014). Peat burning is characterized by distinct burn conditions at low temperatures $\left(<600^{\circ} \mathrm{C}\right)$, resulting in incomplete combustion. Thus, deep smoldering burns are essentially independent of surface conditions (e.g., weather), and may persist for long periods of time, allowing the burns to spread deep into the ground and across large areas. It has been demonstrated in field observations and laboratory studies that burning of peatlands - both tropical and boreal-emits large amounts of greenhouse gases (Stockwell et al., 2014) and hazardous air pollutants (Turetsky et al., 2015; George et al., 2016). Moreover, peat accumulates particulate matter deposited by precipitation (Steinnes et al., 2005) which can be released back into the atmosphere during bog fires.

Smoldering of peatlands was found to be an important emission source, because it may release up to six times more aerosol mass per unit of carbon combusted than grassland flaming fires (Page et al., 2004). Specifically, peat burning emits more hygroscopic particles than grass fires (Gras et al., 1999). The smoldering process is propelled by the heat released from heterogeneous oxidation of the fuel as it reacts with oxygen in the atmosphere (Ohlemiller et al., 1985). Smoldering chemistry can be described by a two-step process, including pyrolysis of organic matter, producing pyrogenic char which is subsequently oxidized (Hadden et al., 2013). Slow and low-temperature smoldering fires yield a considerably higher conversion of fuel to toxic compounds compared to flaming burns (Alves et al., 2017). Such fires generate brown carbon $(\mathrm{BrC})$, consisting mainly of weakly light-absorbing organic carbon compounds (Kirchstetter and Thatcher, 2012; Popovicheva et al., 2017b).

The effect of peat fires on atmospheric chemistry in downwind regions was demonstrated for several haze episodes in Southeast Asia (See et al., 2007; Engling et al., 2014; Xu et al., 2015). Specifically, the increase in concentrations of molecular markers for biomass combustion, such as levoglucosan, by up to two orders of magnitude and the diagnostic ratios of specific organic compounds (e.g., levoglucosan/mannosan ratio) showed that biomass burning emissions can cause regional haze episodes due to long-range transport of smoke aerosol by prevailing winds. In order to make more accurate estimates of the contribution of smoke aerosols from boreal peat land fires, detailed chemical and optical characterization of representative real-world emissions is crucial. In laboratory combustion studies it is shown that peat burning yields significantly larger emissions of total fine particles compared to other biofuels (Iinuma et al., 2007b). Smoke particles emitted from burning of Alaskan and Siberian peat are predominantly comprised of $\mathrm{BrC}$ with small amounts of black carbon (Chakrabarty et al., 2016).

In order to assess the impacts of peat fires on the aerosol/climate system in boreal regions, during this study a near-source sampling campaign was undertaken in a peat bog region in the central European part of Russia, that was subject to large-scale burning in spring and summer of 2014, and concurrently at an urban down-wind location. Carbon fractions, functionalities of organic/inorganic compounds, markers of biomass burning (anhydrosaccharides), ionic composition, and microstructure of smoke particles were analyzed. Extended cluster analysis was then used to assess the multicomponent structure of peat smoke according to individual particle morphology and chemical composition, showing the abundance and variability of micromarkers representative of specific particle types for peat bog smoldering. The main objective of this study is to reduce a knowledge gap by assessing the chemical, physical, and spectrally-resolved optical properties of aerosols freshly emitted by peat smoldering and aged aerosol following transport of smoke plumes to Moscow city.

\section{EXPERIMENTAL}

\section{Sampling Campaigns}

The early arrival of spring in 2014 and an unusually small amount of snow during winter resulted in fires 
commencing in late March in abandoned peat mines in the Tver region, north of Moscow city. Once ignited, these fires were particularly difficult to extinguish despite rainfall, weather changes, and fire-fighting attempts. By late July, twelve fires had been registered in the region north of Moscow city, covering a total area of 4.7 hectares. On 1 August the temperatures approached the record value of $35^{\circ} \mathrm{C}$. On that day concentrations of air pollutants such as carbon monoxide and nitrogen oxides exceeded the maximum permissive values by 1.3 and 1.4 times, respectively (http://www.rg.ru/2014/08/01/ekologia-site.html). By 3 August two large peat bog fires had reached an intensity that resulted in smoke emissions affecting a large territory up to Moscow city. On 5-7 August additional fires were registered in the Tver region, totally covering an area of nearly 130 hectares.

With the main purpose to characterize particulate emissions from peat fires, a near-source sampling campaign was performed in the area of intensive peat smoldering, i.e., in the Tver region, approximately $100 \mathrm{~km}$ north of Moscow city $\left(56.7^{\circ} \mathrm{N}, 36.3^{\circ} \mathrm{E}\right)$, on 15 August 2014. Visual observation of the area showed widely spreading white smoke (Fig. 1(a)). The most typical emission type was smoke rising from underground fires through the surface grass. The density of smoke above grass was variable, ranging from thin to strong. Thin smoke from underground was observed in places of absence of any grass (Fig. 1(b)). At times, this smoke caused ignition of grass, as shown in Fig. 1(c).

Samples were collected from smoke inside grass, smoke of various density above grass as well as smoke rising from underground burns. Total suspended particulate (TSP) matter was collected on quartz fiber filters (Tissuquartz, PALL) for $7-15 \mathrm{~min}$ at a flow rate of $20 \mathrm{~L} \mathrm{~min}^{-1}$. In addition, metal substrates (Ti foil) were used for fine particle collection by means of a custom-made 2-stage cascade impactor with size cutoffs at 10 and $0.65 \mu \mathrm{m}$ aerodynamic diameter, operating at a flow rate of $5 \mathrm{~L} \mathrm{~min}^{-1}$. Only samples of strong smoke inside grass could be collected on metal substrates for individual particle analyses.

The episode of peat smoke plume transport to the megacity was investigated at a site in the south-western part of Moscow city $\left(55.42^{\circ} \mathrm{N}, 37.31^{\circ} \mathrm{E}\right)$, with measurement equipment located $60 \mathrm{~m}$ above ground in a building of Moscow State University (MSU). Aerosol sampling was performed in the period from 31 July to 18 August 2014. Mass concentrations of aerosols less than $10 \mu \mathrm{m}$ diameter $\left(\mathrm{PM}_{10}\right)$ were measured by State Environmental Protection Institution "Mosecomonitoring" at the Meteorological Observatory of MSU using a tapered element oscillating microbalance (TEOM Series 1400a Ambient Particular Monitor; Thermo Environmental Instruments Inc., USA). Depending on $\mathrm{PM}_{10}$ loadings (high, medium or low) the sampling time was chosen to be 24,48 , or $72 \mathrm{~h}$ for the periods of 31 July; 1, 4, and 11-13 August; 2-3 August; and 8-10 and 15-18 August, respectively.

Backward trajectories were generated to visualize the atmospheric transport and evaluate the general flow patterns of air masses during sampling days. The NOAA HYbrid Single-Particle Lagrangian Integrated Trajectory (HYSPLIT) model of the Air Resources Laboratory (ARL) (Stein et al., 2015) was used. The potential source areas were investigated using 1-day back trajectories for air masses arriving every 6 hours at 250, 500 and $1000 \mathrm{~m}$ height above ground level (a.g.l.). No qualitative differences were observed for these heights with respect to the direction of air mass transport.

Fire maps for the study period were obtained by the Fire Information for Resource Management System (FIRMS), operated by the NASA/GSFC Earth Science Data Information System (ESDIS). Daily maps were related to the computed trajectories, providing a depiction of the geographical location of fires predominantly in the flaming phase. The major uncertainty in assessing the fire activity was related to the inability of FIRMS to detect smoldering fires, while peat bog burning typically proceeds almost exclusively in the smoldering phase. Therefore, if air masses arrived from north and north-west, we considered them to be associated with some fire activity.

\section{Chemical Analyses}

Carbonaceous aerosol components, i.e., organic and elemental carbon (OC, EC), were measured by taking a punch $\left(2.26 \mathrm{~cm}^{2}\right)$ from each quartz filter and subjecting it

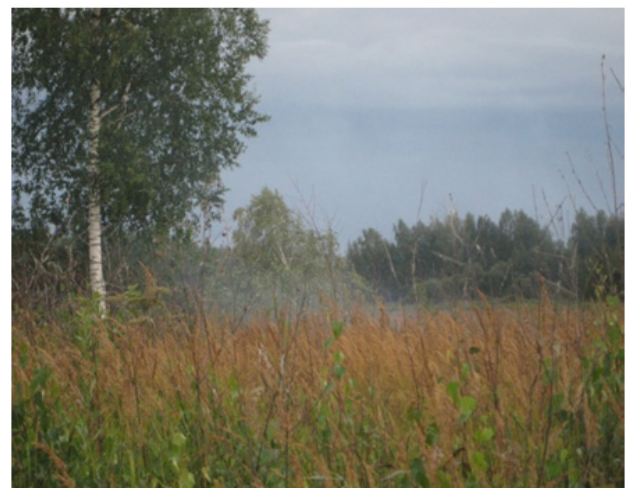

(a)

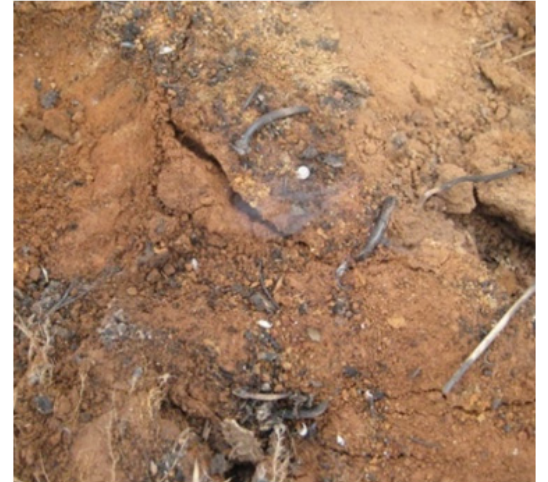

(b)

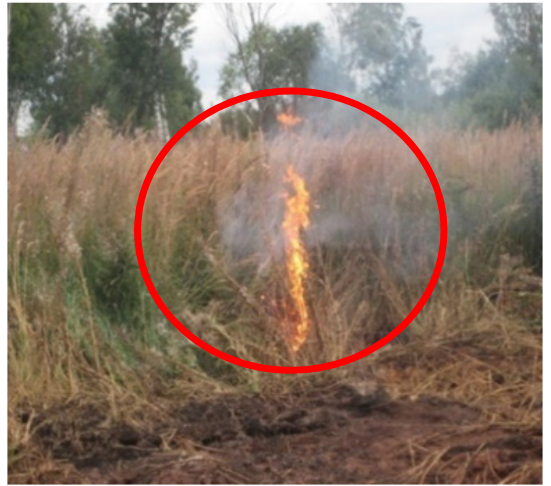

(c)

Fig. 1. Images of (a) persistent peat bog smoldering, (b) underground smoke, and (c) occasional grass flaming in the Tver region in August 2014. 
to thermal-optical transmittance (TOT) analysis with an OC/EC analyzer (Model 4; Sunset Laboratories, Tigard, OR, USA), following the NIOSH protocol (Birch and Cary, 1996).

Inorganic and organic ions were quantified by capillary electrophoresis, using a Capel 103 system (Lumex, Russia) with UV detection. Filter samples were extracted in $5 \mathrm{~mL}$ deionized water by ultrasonic agitation for $45 \mathrm{~min}$ and then filtered. Inorganic anions $\left(\mathrm{SO}_{4}{ }^{2-}, \mathrm{NO}_{3}{ }^{-}, \mathrm{Cl}^{-}, \mathrm{F}^{-}\right.$, and $\mathrm{PO}_{4}{ }^{3-}$ ) and cations $\left(\mathrm{Na}^{+}, \mathrm{NH}_{4}^{+}, \mathrm{K}^{+}, \mathrm{Mg}^{2+}\right.$, and $\left.\mathrm{Ca}^{2+}\right)$ as well as organic anions $\left(\mathrm{HCOO}^{-}, \mathrm{CH}_{3} \mathrm{COO}^{-},\left(\mathrm{COO}^{-}\right)_{2}\right)$ were measured in aqueous extracts. A mixture of benzimidazole, tartaric acid, and 18-crown-6-ether was used as electrolyte for cation separation. Anions were analyzed in a chromate buffer prepared from chromium oxide (VI), diethanolamine, and cetyltrimethylammonium hydroxide solutions. The detection limits for ion concentrations were in the range of $0.1-$ $0.5 \mu \mathrm{g} \mathrm{mL}^{-1}$.

Because of unpredictable spatial-temporal variability of emissions in the peat bog environment total PM mass of smoke emissions was difficult to measure accurately. It was, therefore, computed by summing the mass concentrations of $\mathrm{EC}$, organic matter $(\mathrm{OM})$, and inorganic species:

$\mathrm{PM}=\mathrm{EC}+\mathrm{OM}+\sum$ inorganic species.

The concentration of particulate OM, including watersoluble OM, was estimated by multiplying the measured OC concentrations by a conversion factor $f$, accounting for associated $\mathrm{O}, \mathrm{H}, \mathrm{N}$ and other elements, from the $\mathrm{C}$ mass concentrations attributed to OC. This factor, which is an estimate of the average molecular weight per carbon weight for the organic aerosols, was chosen to be 1.4 (Engling et al., 2014).

Water-soluble organic carbon (WSOC) was measured in aqueous sample extracts with a TOC analyzer (Aurora 1030W; OI Analytical, College Station, TX, USA). Water extraction of particulate filters was performed with deionized ultra-pure water, followed by filtration with Teflon syringe filters. The analytical process includes oxidation of soluble carbon-containing compounds to carbon dioxide, which is quantified by a non-dispersive infrared gas analyzer. Subsequently, the inorganic carbon is measured by acidifying the sample and converting all carbonates, hydrogen carbonates and dissolved carbon dioxide to carbon dioxide, which is volatilized by bubbling air through the aqueous sample (Engling et al., 2014). Ultimately, WSOC is determined as the difference between the total and inorganic carbon. The Water Insoluble Organic Carbon (WISOC) is computed by subtracting the measured WSOC values from the OC values. The concentration of particulate water-soluble and insoluble OM (WSOM and WISOM) was estimated by multiplying the measured concentrations of WSOC and WISOC by a conversion factor $f$. Quality control and assurance (QA/QC) measures included the analysis of blank samples.

Organic molecular markers for biomass burning include the anhydrosaccharides (levoglucosan, mannosan and galactosan) (Simoneit et al., 1999). These carbohydrates were separated, identified, and quantified by high-performance anion exchange chromatography coupled with pulsed amperometric detection (HPAEC-PAD). A Dionex ICS-3000 system (Dionex Corp., Sunnyvale, CA, USA) was utilized, consisting of a dual pump module, dual conductivity detector/chromatography compartment, and auto-sampler. The separation of the carbohydrate species was carried out on a Dionex Carbopac MA1 analytical column $(250 \times 4 \mathrm{~mm})$ preceded by a guard column. An aqueous sodium hydroxide solution $(\mathrm{NaOH} ; 480 \mathrm{mM})$ was used as eluent at a flow rate of $0.4 \mathrm{~mL} \mathrm{~min}{ }^{-1}$. None of the carbohydrate species were detected in blank samples. A more detailed description of the analytical method can be found elsewhere (Engling et al., 2006a; Zhang et al., 2013). Additional carbohydrate species, including arabitol, mannitol, threitol and 2-methyl tetrols, were quantified by HPAEC-PAD as well, and used as molecular markers for different emission sources.

Fourier-transform Infrared Spectroscopy (FTIR) measures the light absorbance associated with the frequency of the bond motion and thus reveals the nature of the functional groups representing the various classes of organic compounds in the entire aerosol composition. FTIR spectra of filter samples were collected with an IRPrestige-21 spectrometer (Shimadzu Corp., Kyoto, Japan) in attenuated total reflection (ATR) mode using a ZnSe crystal. Spectra were recorded in the range from 450 to $4000 \mathrm{~cm}^{-1}$ with a resolution of $4 \mathrm{~cm}^{-1}$. IR Solution software was applied to subtract the FTIR spectrum of blank substrates and correct the baseline absorbance. The range of $750-1250 \mathrm{~cm}^{-1}$ was cut due to intensive absorption of the blank filter in this region. FTIR spectra of water extracts of filter samples were analyzed with the purpose to detect water-soluble compounds. After ultrasound extraction of a filter punch (diameter of $12.5 \mathrm{~mm}$ ) in $5 \mathrm{~mL}$ of distillated water during $50 \mathrm{~min}$, a droplet of the extract was placed on the ZnSe crystal and left until it was evaporated. FTIR spectra of the dried deposit were collected. Because of the possible overlapping of vibration bands the functionality identification was accomplished through the use of the Shimadzu FTIR database and a set of authentic chemical standards measured in the same FTIR setup, as described elsewhere (Popovicheva et al., 2015b, 2017a), and applied in previous studies (Maria et al., 2002; Coury and Dillner, 2009).

Off-line examination of light attenuation on quartz filter samples was performed using a multiple-wavelength light transmission instrument (transmissometer), based on the method described in Kirchstetter et al. (2004). The intensity of light transmitted through quartz filters was measured at seven wavelengths from the near-ultraviolet to near-infrared spectral region. Five to seven different spots were exposed to evaluate the homogeneity of the filter sample. The light absorption is approximated by light attenuation (ATN) caused by the particle deposit, defined as follows:

$$
A T N=\ln \left(\frac{I_{o}}{I}\right),
$$

where $I_{o}$ and $I$ are the light intensity transmitted through 
unexposed and exposed parts of the filter, respectively. The dependence of ATN on the wavelength $\lambda$ was parameterized using a power law relationship:

$A T N=\mathrm{k} \lambda^{-\mathrm{AAE}}$

where the Absorption Angstrom Exponent (AAE) is a measure of strength of the spectral variation of aerosol light absorption.

The microstructure for peat smoke inside grass was obtained by individual particle analyses. Morphology and elemental composition was determined with a LEO 1430-vp (Karl Zeiss) field emission scanning electron microscope (SEM) with a spatial resolution of $7 \mathrm{~nm}$, equipped with an Oxford energy dispersive detector (INCA; Oxford Instruments plc, Abingdon, UK). Energy dispersive X-ray (EDX) spectra for $Z$ elements $(Z \geq 5)$ were recorded in SEM image mode. Samples were examined in the high vacuum mode at $10 \mathrm{kV}$ acceleration voltage and a beam current of $1 \mathrm{nA}$, as described elsewhere (Popovicheva et al., 2016a). Briefly, approximately 500-1000 individual particles with a diameter from 0.1 to $2.5 \mu \mathrm{m}$ are measured. This number is considered to be statistically sufficient for obtaining a representative overview of groups and types of particles (Liu et al., 2000; Popovicheva et al., 2012). EDX analysis yields a data matrix containing $\mathrm{C}, \mathrm{O}, \mathrm{F}, \mathrm{Na}, \mathrm{Mg}$, $\mathrm{Al}, \mathrm{Si}, \mathrm{P}, \mathrm{S}, \mathrm{Cl}, \mathrm{K}, \mathrm{Ca}, \mathrm{Ti}$, and Fe elements at the measured weight concentrations above the detection limit (0.3 wt $\%)$.
Cluster analysis is applied for separation of individual particles into characteristic groups with similar chemical composition. Details of the theoretical approach are described elsewhere (Popovicheva et al., 2012). Groups were separated with an average composition as close as possible to physico-chemically identifiable particle types. Naming of particle groups was based on both morphological features and most abundant elements after $\mathrm{C}$ and $\mathrm{O}$.

\section{RESULTS AND DISCUSSION}

\section{Peat Smoldering Emissions}

Carbon Fractions and Molecular Markers

High carbon content is found in smoke produced by peat burning and collected from underground, inside grass and above grass (Table 1). The mass balance shows that smoke is dominated by OC, while the contribution of ionic species is small (Fig. 2). OC contribution to TC is as high as 91$95 \%$, associated with particle formation due to preferable condensation of volatilized organic compounds (Reid et al., 2005). High OC/TC ratios are typical for smoldering burns of various types of biomass, including mixtures of spruce, pine, and peat used in small-scale fires previously examined in the Moscow region (Popovicheva et al., 2014), as well as during agricultural residue fires (Popovicheva et al., 2016a, 2017b).

The OC/EC ratio is widely used to characterize the origin of pollution, and in case of combustion emissions it

Table 1. Particulate matter (PM), organic carbon (OC), levoglucosan (Lev), mannosan (Man), galoctosan (Gal), total water-soluble ions (TWSI), Absorption Angstrom Exponent (AAE), sugars, ratios for OC/total carbon (TC), OC/elemental carbon (EC), and water-soluble organic carbon (WSOC)/OC in underground smoke, smoke inside and above grass from peat bog smoldering, as well as the maximum values observed during the peat smoke episode at an urban site in the southwest of Moscow city.

\begin{tabular}{|c|c|c|c|c|c|}
\hline & $\begin{array}{l}\text { Thin smoke } \\
\text { inside grass }\end{array}$ & $\begin{array}{l}\text { Thin smoke } \\
\text { above grass }\end{array}$ & $\begin{array}{l}\text { Strong smoke } \\
\text { above grass }\end{array}$ & $\begin{array}{l}\text { Underground } \\
\text { smoke }\end{array}$ & $\begin{array}{l}\text { Maximum values at } \\
\text { Moscow urban site }\end{array}$ \\
\hline \multicolumn{6}{|l|}{ Species } \\
\hline $\mathrm{PM}\left(\mathrm{mg} \mathrm{m}^{-3}\right)$ & 13.2 & 5.4 & 8.4 & n.d. & 0.097 \\
\hline $\mathrm{OC}\left(\mathrm{mg} \mathrm{m}^{-3}\right)$ & 8.9 & 3.5 & 5.3 & n.d. & 0.015 \\
\hline $\operatorname{Lev}\left(\mu \mathrm{g} \mathrm{m}^{-3}\right)$ & 67.9 & 27.3 & 46.1 & 5.1 & 0.108 \\
\hline $\operatorname{Man}\left(\mu \mathrm{g} \mathrm{m}^{-3}\right)$ & 14.6 & 5.8 & 10.0 & 1.4 & 0.020 \\
\hline $\mathrm{Gal}\left(\mu \mathrm{g} \mathrm{m}^{-3}\right)$ & 24.2 & 10.1 & 24.4 & 4.1 & 0.001 \\
\hline TWSI ( $\left.\mathrm{mg} \mathrm{m}^{-3}\right)$ & 0.3 & 0.3 & 0.5 & 0.2 & 0.018 \\
\hline AAE & 4.1 & 4.3 & 4.2 & 4.0 & 1.3 \\
\hline \multicolumn{6}{|l|}{ Sugars } \\
\hline Arabitol $\left(\mu \mathrm{g} \mathrm{m}^{-3}\right)$ & 1.8 & 2.5 & 4.2 & 0.5 & 0.035 \\
\hline Mannitol $\left(\mu \mathrm{g} \mathrm{m}^{-3}\right)$ & 1.7 & 2.5 & 3.3 & 0.4 & 0.041 \\
\hline Methyl-threitol $\left(\mu \mathrm{g} \mathrm{m}^{-3}\right)$ & n.d. & 6.0 & 2.0 & n.d. & 0.103 \\
\hline Threitol $\left(\mu \mathrm{g} \mathrm{m}^{-3}\right)$ & 0.7 & 1.8 & 1.9 & 0.7 & 0.164 \\
\hline \multicolumn{6}{|l|}{ Ratios } \\
\hline OC/TC $(\%)$ & 95 & 92 & 91 & n.d. & 86 \\
\hline $\mathrm{OC} / \mathrm{EC}$ & 19.3 & 13.3 & 9.8 & n.d. & 7 \\
\hline Lev/OC (\%) & 7.6 & 7.7 & 8.7 & n.d. & 1.7 \\
\hline WSOC/OC (\%) & 8.8 & 37 & 21 & n.d. & 40 \\
\hline $\mathrm{K}^{+} / \mathrm{EC}(\%)$ & 3.2 & 4.1 & 6.0 & n.d. & 77 \\
\hline Lev/Man & 4.6 & 4.7 & 4.6 & 3.5 & 10.7 \\
\hline $\mathrm{K}^{+} / \mathrm{Lev}$ & 0.2 & 0.4 & 0.6 & 2.12 & 4.1 \\
\hline
\end{tabular}

n.d. - not detected. 

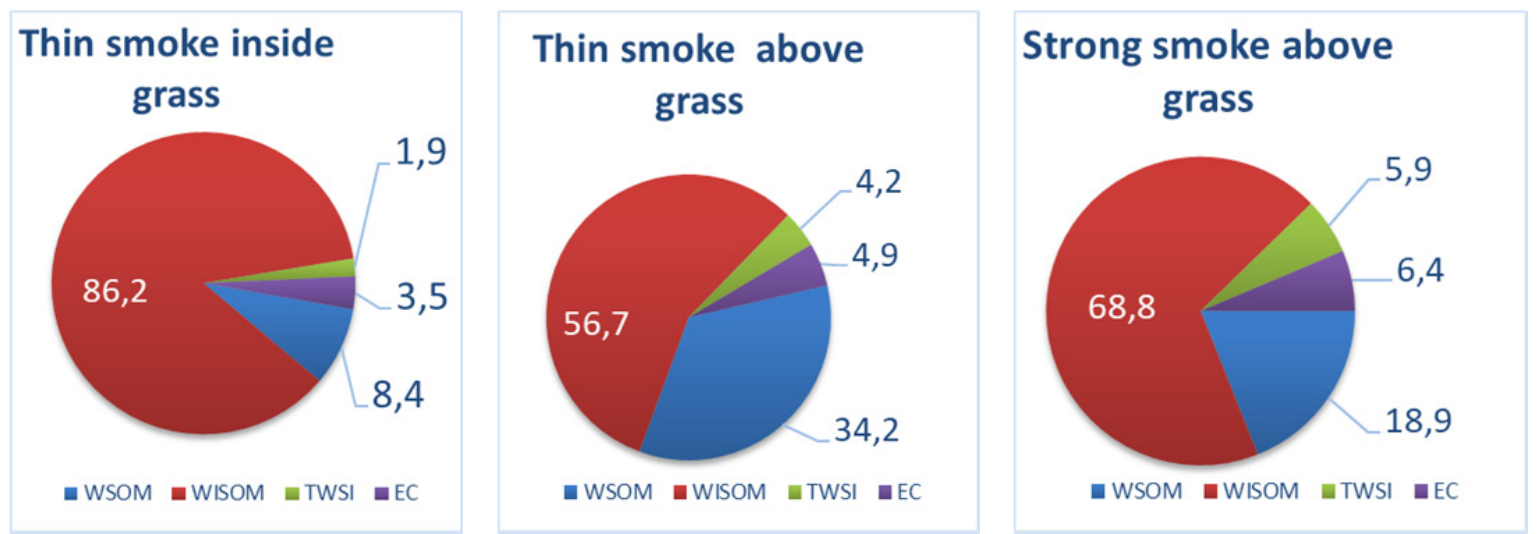

Fig. 2. Mass balance of carbon fractions and ions in PM mass from thin smoke inside and above grass, and strong smoke above grass. Relative abundance of elemental carbon (EC), water-soluble organic matter (WSOM), water-insoluble organic matter (WISOM), and total water-soluble ions (TWSI) are shown in percent.

depends strongly on the type of fire and fuel. A small ratio $(<2)$ is more representative for flaming combustion, while significantly higher values are characteristic of smoldering phase burns (Reid et al., 2005; Mikhailov et al., 2017). In chamber studies, smoldering fires of Siberian pine and debris produced almost exclusively organic particles with high OC/EC ratios of 194 and 34, respectively (Popovicheva et al., 2015c). Similar results of dominance of OC versus EC were observed for peat burns by Chakrabarty et al. (2006), with average OC/EC ratios ranging between 70 and 85 for smoldering of Siberian peat and between 23 and 72 for Alaskan peat. In another study, the average OC/EC ratio was found to be 14 and 13 for Indonesian and German peat, respectively (Iinuma et al., 2007b). In smoldering emissions from regional biomass fires around Moscow, we have obtained an average $\mathrm{OC} / \mathrm{EC}$ ratio of 56 , which is in good agreement with those chamber studies (Popovicheva et al., 2014).

In thin smoke from peat burning collected from inside grass $\mathrm{OC} / \mathrm{EC}$ is found to be 19.3 , while in thin and strong smoke above grass it is only 13.3 and 9.8 , respectively (Table 1). This finding once more confirms that the smoldering phase of combustion is characterized by high OC/EC ratios. Comparable values (12.7) were found for agricultural fires in form of crop residue and steppe grass burning in Siberia (Mikhailov et al., 2017).

Spectral absorption measurement of biomass burning emissions shows the combined impact of both BC (absorbing from 670 to $500 \mathrm{~nm}$ ) and $\mathrm{BrC}$ which enhances the absorption below $500 \mathrm{~nm}$ (Kirchstetter et al., 2004). Weak spectral dependence of ATN with AAE around 1 was observed for diesel soot and urban aerosols (Kirchstetter et al., 2004) due to the abundance of BC derived from hightemperature combustion of fossil fuels. Similar results for traffic emissions were obtained in a megacity with AAE equal to 1.3 (Popovicheva et al., 2017b), indicating that traffic produces significantly less $\mathrm{BrC}$ and more EC than biomass burning. For comparison, AAE obtained in chamber studies by photoacoustic nephelometry was as high as 9 for Alaskan and Siberian peat burning (Chakrabarty et al., 2006), thus indicating AAE as a source-specific optical marker for potential impact of peat bog smoldering on urban aerosols.

Peat bog smoke samples collected in the Tver region appeared more brown than black, rendering them as absorbers of solar radiation with stronger wavelength selectivity in the blue and ultraviolet regions. Spectral dependence of the light attenuation measured for peat burning smoke is shown in Fig. 3. It can be well approximated by a power law relationship (2). The AAE is around 4.2 for both smoke emissions from underground fires inside and above grass (Table 1), demonstrating a strong wavelength dependence of the predominant $\mathrm{BrC}$ component. Kirchstetter et al. (2004) and Popovicheva et al. (2017b) reported similar high values of 2.5 and 3.2 for smoke of savanna fires and rice straw burning, respectively. Sun et al. (2007) examined numerous organic compounds of light absorbing organic carbon and showed that they are probably oxygenated and multifunctional, and have very high molecular weight. Therefore, we can expect a significant amount of polar organic compounds in peat burning smoke as well.

Water-soluble organic carbon (WSOC) relates to various oxygenated organic compounds released from biogenic sources and biomass burning activities. WSOC contributes to light absorption at both ultraviolet and visible wavenumbers (Chen and Bond, 2010). An investigation of the organic-rich aerosols in the Amazon basin by Mircea et al. (2005) suggested that the molecular characterization of the WSOC fraction as well as inorganic constituents is crucial for evaluating aerosol hygroscopicity. In peat smoke collected from underground fires inside and above grass, WSOM comprised from 4.3 up to $17.9 \%$ of PM mass (Fig. 2), while WSOC/OC ratios are found to range from 10 to $30 \%$ (Table 1). This abundance in polar organic species in the peat smoke particles has important implications on cloud formation, rendering peat burning to be potentially more active cloud condensation nuclei (CCN) due to their hygroscopic character. Implied by the high content of oxygenated compounds, peat burning can increase cloud condensation nuclei (CCN) formation (Koehler et al., 2009), induce SOA formation (Ding et al., 2013), and increase impacts on human health (Baltensperger et al., 2008). 


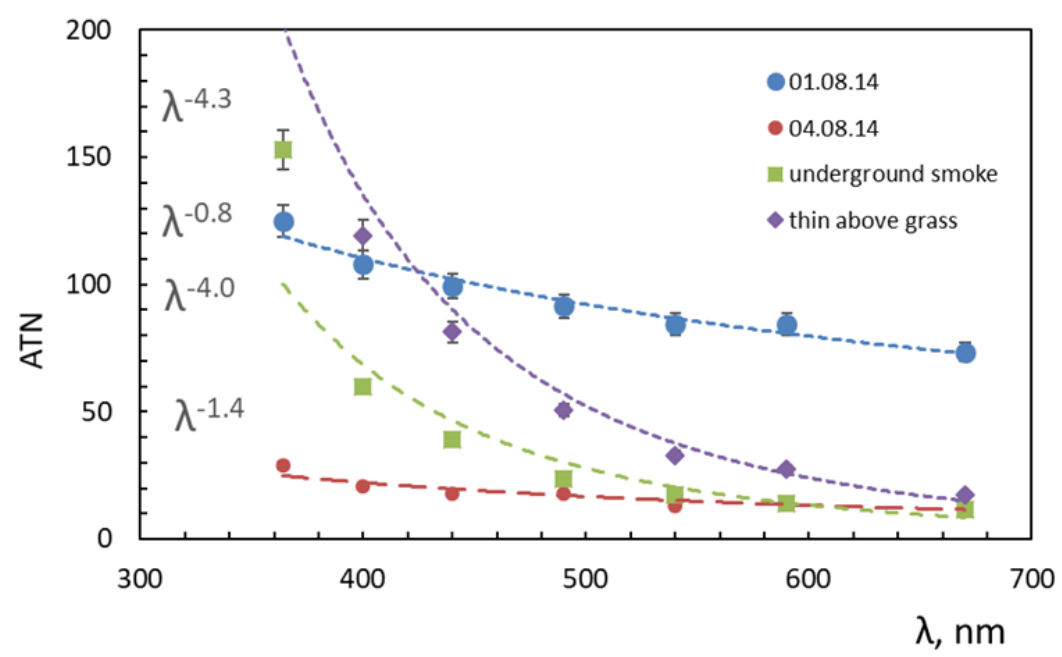

Fig. 3. Light attenuation as a function of wavelength for underground smoke and thin smoke above grass, for day of lowest (01.08.2014) and highest (04.08.2014) values of AAE during sampling period at MSU site. Solid lines were generated using a power law Eq. (2). Values of the exponent for AAE were chosen to fit the data.

Various individual organic compounds, including molecular markers (e.g., anhydrosaccharides) have been quantified in biomass burning emissions (Iinuma et al., 2007a; Popovicheva et al., 2016a). The Lev/OC ratio exhibits a great variability depending on the type of biomass and combustion conditions (Engling et al., 2006b). The levoglucosan mass fraction can represent up to $35 \%$ of OC when burning pine in the smoldering phase, while this marker comprised only $5 \%$ of OC for debris burning in the smoldering phase (Popovicheva et al., 2016b). Because levoglucosan and its two isomers, mannosan and galactosan, are emitted in different relative abundance depending on combinations of burn phase and fuel, the Lev/Man and $\mathrm{Lev} /(\mathrm{Man}+\mathrm{Gal})$ ratios are used to trace the type of biomass burned (Alves et al., 2010). Lev/Man ratios for various biomass species, including softwood (3-6), hard wood (15-25) and straw (30-40), have been reported, with only a few studies measuring these markers in peat smoke emissions. Lev/Man ratios of $\sim 10$ were observed in a chamber peat burning study (Iinuma et al., 2007a) and in ambient aerosol downwind of peatland fires (Engling et al., 2014).

Among saccharides, in peat smoke observed in this study we distinguish anhydrosaccharides where levoglucosan comprises the largest fraction, up to $8.7 \%$ (Table 1), while the isomeric anhydrosaccharides mannosan and galactosan were present at fairly high levels as well. The Lev/Man ratio determined for underground smoke is found to be 3.5; for smoke inside, and above grass it is around 4.2, indicating slightly different carbohydrate composition and providing a fingerprint for peat bog burning smoke. It is interesting to note the value of 3.4 measured in smoke plumes from Siberian forest fires (Jung et al., 2016). Similarly, Lev/Man ratios around 5 were reported for smoke from coniferous forest fires (Schmidl et al., 2008), showing similar relative abundance of the isomeric anhydrosaccharides in these two different types of biomass. Concentrations of sugar alcohols (arabitol, mannitol, methyl- threitol, and threitol) were detected at significantly lower concentrations compared to anhydrosaccharides (Table 1).

\section{Organic/Inorganic Functionalities}

More detailed information about organic and inorganic composition is revealed by analyses of prominent functionalities in FTIR spectra (Fig. 4(a)). Aliphatic, aromatic, carbonate, and aromatic nitro groups were observed in smoke aerosol produced by spruce, pine, and peat small-scale fires in the Moscow region (Popovicheva et al., 2014). Intensive stretches (2929-2852 $\mathrm{cm}^{-1}$ ) and bends $\left(1479 \mathrm{~cm}^{-1}\right)$ of aliphatic C-C-H in alkanes, of carbonyl $\left(\mathrm{C}=\mathrm{O} ; 1739 \mathrm{~cm}^{-1}\right)$ in ethers/lactones and humic acids, of $\mathrm{C}=\mathrm{C}\left(1596 \mathrm{~cm}^{-1}\right)$ in aromatic as well as less prominent $\mathrm{C}=\mathrm{O}\left(1678 \mathrm{~cm}^{-1}\right)$ in aldehydes and carbonates $\left(\mathrm{CO}_{3}{ }^{2-} ; 1425 \mathrm{~cm}^{-1}\right)$ comprise the characteristic pattern of underground smoke. These functionalities are well shown in the absorption features of thin smoke above grass, probably dominated by emissions from underground burns. It is worthwhile to note that organic acids, $n$-alkanes, and $n$-alkenes were observed as dominant organic compound classes in emissions of North Carolina, German, and Indonesian peat burned in chamber studies (Iinuma et al., 2007b; George et al., 2016).

FTIR spectra of thin smoke collected inside grass exhibit considerably different patterns, with characteristic bands of $\mathrm{N}-\mathrm{H}$ in amines overlapping with alkenyl $\mathrm{C}=\mathrm{C}$ in alkenes at $1640 \mathrm{~cm}^{-1}$, of aromatic $-\mathrm{NO}_{2}\left(1534 \mathrm{~cm}^{-1}\right)$, and nitrates $\left(\mathrm{NO}_{3}^{-} ; 1356 \mathrm{~cm}^{-1}\right)$, except aliphatic and carbonyl groups. This dominance of nitrogen-containing compounds is an impact of grass smoldering on peat bog emissions. Prominent stretches $\left(1570 \mathrm{~cm}^{-1}\right)$ and bends $\left(1384 \mathrm{~cm}^{-1}\right)$ of carboxylate $\left(\mathrm{RCOO}^{-}\right.$; salts of carboxylic acids) are observed in strong smoke inside grass. They were found in field burning (Popovicheva et al., 2016a, 2017b) and considered as one of the characteristic features. The bands of aliphatic, carbonyls, amines, nitro compounds, and nitrates observed in strong smoke above grass can be associated with both 
underground smoke and smoke collected inside grass. However, the hydrophilic functionalities of hydroxyl $(\mathrm{OH})$ responsible for effective water uptake (Kuznetsov et al., 2003) are not observed in peat burning smoke, rendering rice straw burning emissions as the most hygroscopic smoke aerosol among various types of biomass (Petters et al., 2009).

Fig. 4(b) shows the absorption bands of water-soluble compounds of peat bog smoke. According to the most hygroscopic species identified in the particle composition (Kireeva et al., 2009; Popovicheva et al., 2016c) we could expect that ionic functionalities such as ammonium, sulfates, nitrates, phosphates, and carbonates would dominate the spectra of water extractable compounds. Underground smoke demonstrates the absorption bands of $\mathrm{NH}_{4}^{+}\left(3278 \mathrm{~cm}^{-1}\right)$, sulfates $\left(\mathrm{SO}_{4}{ }^{2-} ; 1035,1116 \mathrm{~cm}^{-1}\right)$ in ammonium sulfates, nitrates $\left(\mathrm{NO}_{3}{ }^{-} ; 840,1339 \mathrm{~cm}^{-1}\right)$, silicates $\left(\mathrm{SiO}_{4}{ }^{4-} ; 923 \mathrm{~cm}^{-1}\right)$, and carbonates $\left(\mathrm{CO}_{3}^{-} ; 1423 \mathrm{~cm}^{-1}\right)$ as well as of $\mathrm{C}=\mathrm{O}(1754$, $\left.1645 \mathrm{~cm}^{-1}\right)$ in anhydrates and amino acids/acid carbonyls, $-\mathrm{NO}_{2}\left(1527 \mathrm{~cm}^{-1}\right)$ in nitro compounds, and C-N $\left(1204 \mathrm{~cm}^{-1}\right)$ in amines. These functionalities are predominant in thin smoke inside as well as in smoke above grass similar to total aerosol spectra. Strong smoke inside and above grass shows additional bands of $\mathrm{C}=\mathrm{O}\left(1719 \mathrm{~cm}^{-1}\right)$ in carboxylic acids, $\mathrm{C}=\mathrm{C}\left(1592 \mathrm{~cm}^{-1}\right)$ in aromatic compounds, nitrites $\left(\mathrm{NO}_{2}^{-}\right.$; $\left.1489 \mathrm{~cm}^{-1}\right), \mathrm{CO}_{3}{ }^{-}\left(1369 \mathrm{~cm}^{-1}\right), \mathrm{SO}_{4}{ }^{2-}\left(1158 ; 1072 \mathrm{~cm}^{-1}\right)$ in potassium and sodium sulfates, and $\mathrm{SiO}_{4}^{4-}\left(957 \mathrm{~cm}^{-1}\right)$. They indicate water-soluble compounds produced by smoldering of grass.

\section{Ionic Fraction}

Sulfates and chlorides have been identified in biomass as mobile mineral species of authigenic origin due to uptake of water in natural biomass (Vassilev et al., 2012). Sulfate formation during combustion is attributed to gasto-particle conversion of acidic $\mathrm{SO}_{2}$ and $\mathrm{SO}_{3}$ gases, produced from biomass S-containing compounds, and basic alkaline and alkaline-earth ions bound to organic matter of biomass as exchangeable elements, associated with arcanite $\left(\mathrm{K}_{2} \mathrm{SO}_{4}\right)$ and anhydrite $\left(\mathrm{CaSO}_{4}\right)$ (Dare et al., 2001). $\mathrm{SO}_{4}{ }^{2-}, \mathrm{K}^{+}, \mathrm{Cl}^{-}, \mathrm{NO}_{3}^{-}, \mathrm{NO}_{2}^{-}, \mathrm{Na}^{+}, \mathrm{NH}_{4}^{+}$, and $\mathrm{Ca}^{2+}$ are the inorganic ionic species observed in pine and debris burning smoke aerosol (Popovicheva et al., 2015c). In wildfire emissions, calcium sulfates were found to be prominent in the smoke microstructure, in good agreement with increased concentrations of $\mathrm{SO}_{4}{ }^{2-}$ ions (Popovicheva et al., 2014). The presence of sulfates in peat smoke is due to the sulfur content in peat, as observed in Asian peat swamps (Langmann and Graf, 2003). Consequently, $\mathrm{SO}_{2}$ is produced during smoldering combustion of peat, as measured near peat fires in Indonesia (See et al., 2006; See et al., 2007), and subsequently oxidized to sulfates.

In peat bog smoke in this study, the abundance of inorganic anions $\left(\mathrm{SO}_{4}{ }^{2-}, \mathrm{Cl}^{-}\right)$and cations $\left(\mathrm{Na}^{+}, \mathrm{NH}_{4}^{+}, \mathrm{K}^{+}\right.$, $\left.\mathrm{Mg}^{2+}, \mathrm{Ca}^{2+}, \mathrm{Sr}^{2+}\right)$ as well as organic ions $\left(\mathrm{HCOO}^{-}, \mathrm{CH}_{3} \mathrm{COO}^{-}\right)$ shows good correlation (Fig. 5) with the observed sulfate, ammonium, and carboxylate functionalities in the watersoluble aerosol fraction (Fig. 4(b)). The combined ion mass concentration is reported as total water-soluble ion
(TWSI) concentration in Table 1. As for anions, the relative abundance of $\mathrm{SO}_{4}{ }^{2-}$ is the greatest and is about $50 \%$ higher in smoke aerosol from inside and above grass than from underground smoke, as expected in case of gaseous emission and gas-to-particle reactions of $\mathrm{SO}_{2}$ above ground, from which $\mathrm{SO}_{4}{ }^{2-}$ is mainly produced. Sodium $\left(\mathrm{Na}^{+}\right)$is most abundant among cations, followed by calcium $\left(\mathrm{Ca}^{2+}\right)$ and strontium $\left(\mathrm{Sr}^{2+}\right)$. The high relative abundance of $\mathrm{Sr}^{2+}$ should be noted, which is accumulated in peat under influence of specific hydrogeological factors as well as contributed through natural minerals such as celestine $\left(\mathrm{SrSO}_{4}\right)$ and strontianite $\left(\mathrm{SrCO}_{3}\right)$. Biomonitoring of anthropogenic pollution was carried out in the Tula region, south of Moscow, with respect to heavy metals, showing no correlations with anthropogenic loadings (Volkova et al., 2012). Acetates $\left(\mathrm{CH}_{3} \mathrm{COO}^{-}\right)$are the predominant organic ions in peat smoke, although their relative abundance is comparable with other ionic species, in contrast to emissions from field burning of rice straw and other agricultural fires (Popovicheva et al., 2016a).

Potassium $\left(\mathrm{K}^{+}\right)$ion is widely used as marker of biomass burning, with PM fractions depending on biomass type (Reid et al., 2005; Alves et al., 2010). However, it was found to not be appropriate for Indonesian peatland fires due to very low concentrations associated with smoldering fires at low temperatures (Fujii et al., 2015). Concentrations of $\mathrm{K}^{+}$ion in peat smoke in our study also are found to comprise only a small fraction (around 7\%) of TWSI (Fig. 5). For comparison, in rice straw burning emissions $\mathrm{K}^{+}$ions comprised 14\% of TWSI (Popovicheva et al., 2017b). Andreae (1983) proposed the $\mathrm{K}^{+} / \mathrm{EC}$ ratio as a diagnostic ratio, suggesting values of 0.2 to 0.5 for biomass burning. An average $\mathrm{K}^{+} / \mathrm{EC}$ ratio of 0.2 obtained during a wildfire smoke event was well within the values obtained for smoldering and flaming phase of regional biomass (Popovicheva et al., 2014). In peat smoke we obtained $\mathrm{K}^{+} / \mathrm{EC}$ varying from 0.03 to 0.06 (Table 1 ), which is lower than expected for other biomass burning emissions. In a previous chamber study, the evolution of smoke from flaming burns led to a noticeable increase in the abundance of $\mathrm{K}$ by a factor of three, while it remained nearly constant in smoldering smoke particles (Popovicheva et al., 2015c). This finding confirms that $\mathrm{K}^{+}$can serve as a better marker for emissions from flaming than smoldering burns.

$\mathrm{A} \mathrm{K}^{+} / \mathrm{Lev}$ ratio of 33.3 was found for the flaming phase, while lower ratios $(0.2-0.6)$ were characteristic for the smoldering phase in savanna fires (Gao et al., 2003). Ratios lower than $0.25-1$ were reported for $\mathrm{PM}_{2.5}$ emissions from wood stove combustion of tree species and pine forest fires (Fine et al., 2004). In our study, $\mathrm{K}^{+} / \mathrm{Lev}$ ratios were 2.12 for underground smoke, and ranged between $0.18-$ 0.62 for smoke inside and above grass, qualitatively corresponding well to smoldering phase combustion.

\section{Peat Burning Morphology and Elemental Composition}

Analysis of individual particles in combustion emissions reveals the complex morphological and chemical composition of carbonaceous particles which are internally and externally mixed with inorganic fly ash and dust (Liu et al., 2000; 

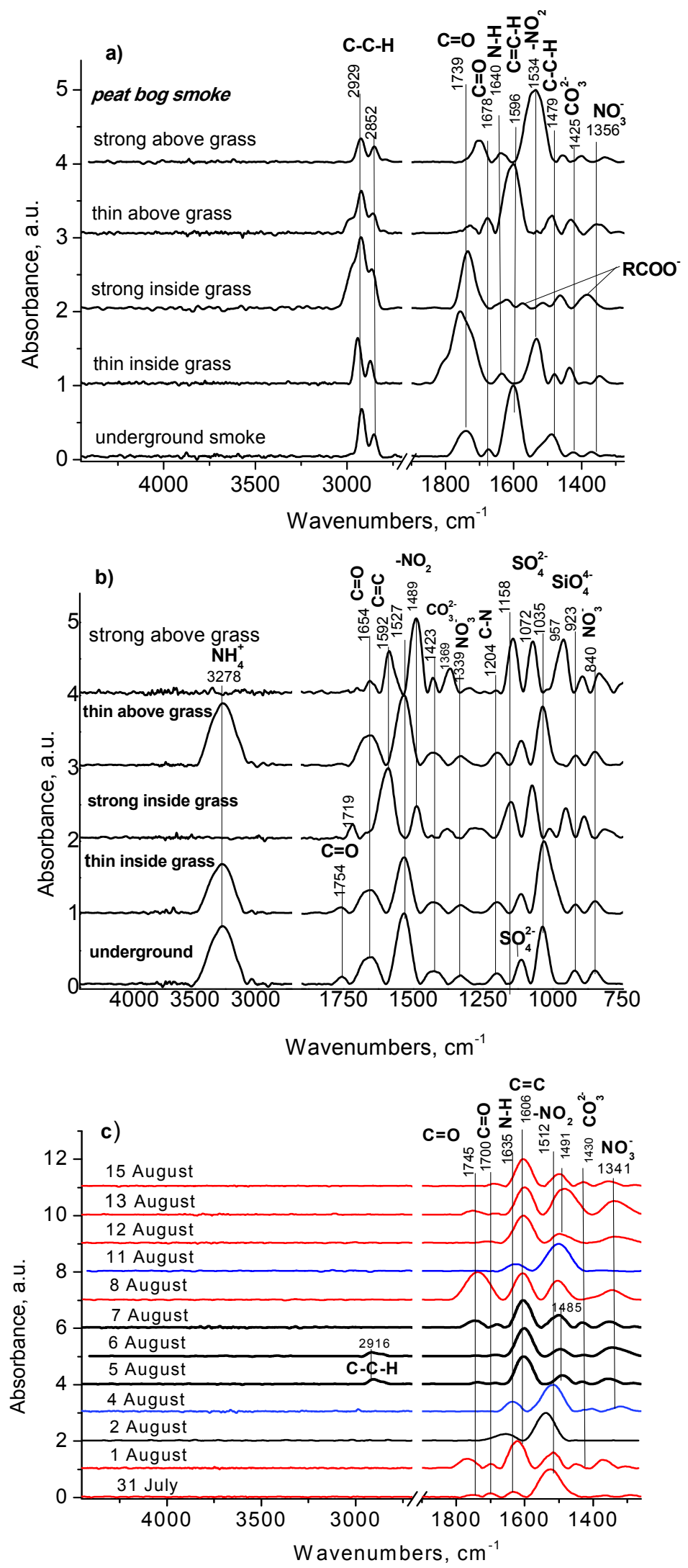

Fig. 4. FTIR spectra of (a) peat bog smoke, and (b) water-soluble compounds in peat bog smoldering emissions. Spectra of underground smoke, smoke inside and above grass, are presented separately. FTIR spectra of (c) ambient aerosols during the sampling period at MSU site; spectra with similar bands demonstrating the identical composition of aerosols are indicated by the same color. Peak wavenumbers and corresponding functionalities are indicated. 


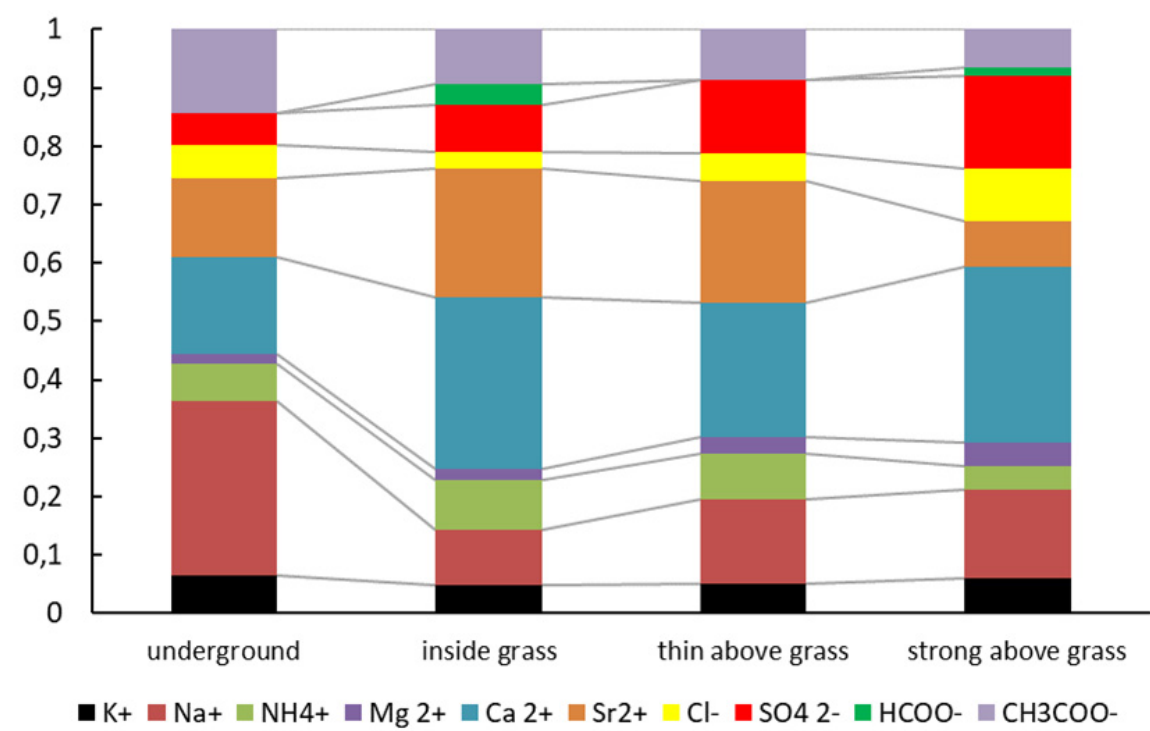

Fig. 5. Relative abundance of inorganic and organic ions in water-soluble fraction in underground smoke, thin smoke inside grass, thin and strong smoke above grass.

Osán et al., 2002; Popovicheva et al., 2015a). Cluster analyses of particles produced during low-temperature combustion in chamber studies show a strong relation to typical properties observed in the smoldering phase, such as the high abundance of organic particles, expressed in high OC/EC ratios, and the small amount of fly ash due to low quantities of elemental constituents in biomass (Popovicheva et al., 2015c). Spherical and agglomerates of spherical shapes of tar balls with amorphous internal structure render them as the major particle type produced by Alaskan and Siberian peat burning (Chakrabarty et al., 2016). Indonesian forest fires emitted individual particles with very high weight ratios of $\mathrm{S} / \mathrm{K}$ due to sulfur-rich peat burning below ground and producing large amounts of $\mathrm{SO}_{2}$ (Ikegami et al., 2001).

The major elements in various biomass types, in decreasing order of abundance, are generally $\mathrm{C}, \mathrm{O}, \mathrm{H}, \mathrm{N}$, $\mathrm{Ca}, \mathrm{K}, \mathrm{Si}, \mathrm{Mg}, \mathrm{Al}, \mathrm{S}, \mathrm{Fe}, \mathrm{P}, \mathrm{Cl}, \mathrm{Na}, \mathrm{Mn}$, and Ti (Vassilev et al., 2012). The composition of individual particles in peat smoke inside grass varies over a wide range of $\mathrm{C}$ and $\mathrm{O}$, as well as 19 trace elements. All particles in peat smoke are found to be predominantly carbonaceous, i.e., their major elements are $\mathrm{C}$ and $\mathrm{O}$. The abundance of trace elements in smoke particles is shown in Fig. 6, indicating $\mathrm{S}, \mathrm{Ca}, \mathrm{Al}, \mathrm{Si}$, $\mathrm{Fe}, \mathrm{Mg}, \mathrm{P}$, and $\mathrm{K}$ as the most frequently distributed elements after $\mathrm{C}$ and $\mathrm{O}$. The average weight percent is dominated by trace elements $\mathrm{Fe}, \mathrm{Al}, \mathrm{Ca}, \mathrm{Si}$, and $\mathrm{S}$ (Fig. 6). $\mathrm{K}$ is distributed over 3\% of smoke particles (Fig. 9), and almost all particles contain also $\mathrm{Al}, \mathrm{Si}, \mathrm{Fe}$, and $\mathrm{Ca}$, typical composition for various aluminosilicates in soil. Since $\mathrm{K}$ is also present as cation in soil aluminosilicates, we may conclude that potassium measured in peat smoke is almost entirely of natural soil origin. The $\mathrm{S} / \mathrm{K}$ ratio obtained here is 6 , while it was observed with median values of $2-4$ during forest fires, and higher $\mathrm{S} / \mathrm{K}$ ratios were reported for a peat burning area in Indonesia (9-18) (Ikegami et al., 2001). $\mathrm{S} / \mathrm{K}$ ratios with an average value of 2.2 were found for individual particles in a Moscow suburb in August 2010. In comparison, this ratio was only 0.16 for spruce flaming smoke, indicating significant oxidation of $\mathrm{SO}_{2}$ released by peat bog fires and subsequent formation of large amounts of sulfates.

Groups of particles from thin peat smoke inside grass obtained by cluster analyses are presented in Fig. 7. The most abundant group $(78.5 \%)$ contains mainly C $(87 \%)$ and $\mathrm{O}(12 \%)$, and is assigned to Group Organic. Tar ball particles were observed with roughly spherical morphology (Fig. 8(1)) formed by bimolecular homogeneous nucleation of polar organic matter with water vapor (Hand et al., 2005). A significant fraction of particles are agglomerates of tar ball spheres (Fig. 8(2)), suggesting a diffusion-limited collisional growth mechanism involved in the formation process. Such morphology is consistent with observations of tar balls in chamber and ambient biomass smoldering studies (Pósfai et al., 2003; Chakrabarty et al., 2010) and significantly different from soot agglomerates of fine primary particles found during high-temperature combustion in the flaming phase (Popovicheva et al., 2015c). Around $30 \%$ of particles in Group Organic contain sulfur up to $4 \%$ (Fig. 8(3)), correlating well with sulfate ion measurements in the bulk composition. Group Organic reveals a common impact of smoldering on morphology and composition of smoke particles, and can serve as a micromarker of peat burning, similar to the observations for burning pine and debris (Popovicheva et al., 2015c) and agricultural field burning emissions (Popovicheva et al., 2016a).

Other particles found in peat smoke are rich in elements which are present in peat and vaporized during combustion, producing internally/externally mixed fly ash. Also, soil minerals evolved by hot convection during fires (Kavouras et al., 2012) can impact the particle composition. Group $\mathrm{Ca}$-, $\mathrm{Si}$-, and $\mathrm{Fe}$-rich is found at significantly lower abundance $(13.5,4.4,3.5 \%)$, respectively, compared to Group Organic (Fig. 7). These particles show crystalline 
(a)

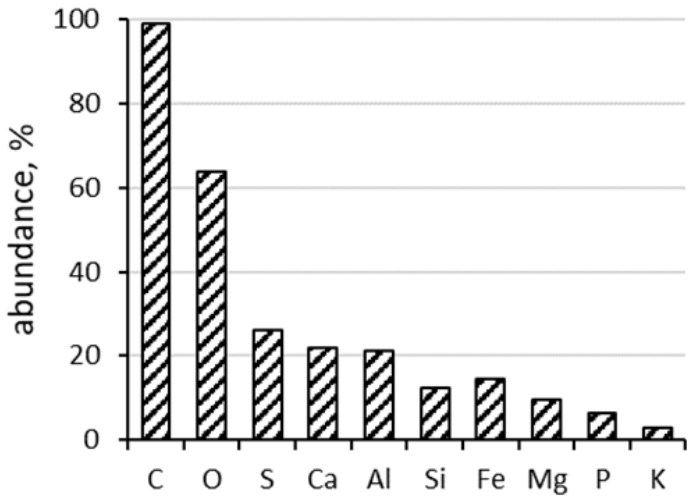

(b)

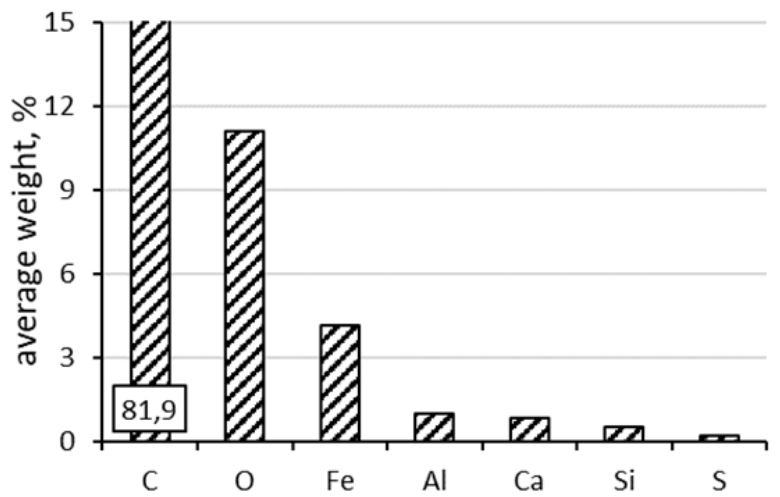

Fig. 6. (a) Abundance of elements in smoke particles and (b) average weight percentages of elements in peat smoke inside grass. Elements with an abundance of less than $2 \%$ are not shown.

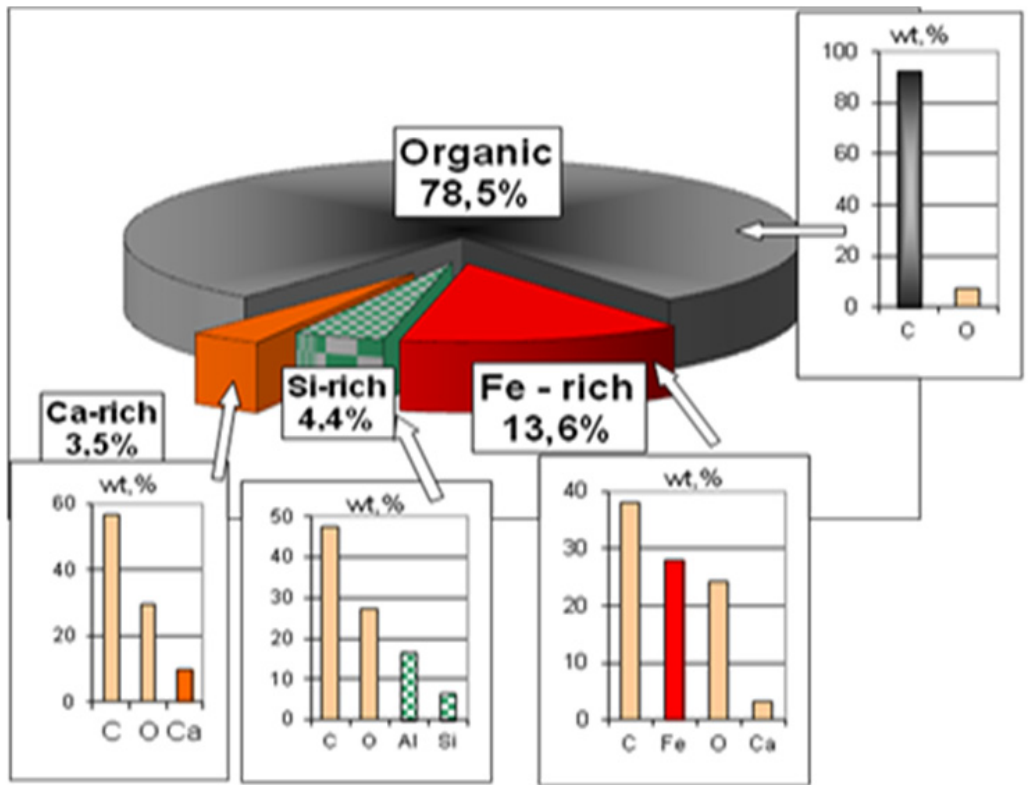

Fig. 7. Grouping of smoke particles inside grass during peat bog smoldering. Naming, relative abundance, and averaged weight percentage of elements in each group are indicated.

morphological features of irregularly shaped particles (Fig. 8). According to the average composition (Fig. 7), Group $\mathrm{Ca}$-, $\mathrm{Fe}$-, and $\mathrm{Si}$-rich is composed from aluminosilicates with $\mathrm{Fe}$ and $\mathrm{Ca}$ inclusions (Fig. 8(4)), iron oxides (Fig. 8(5)), and calcium oxides/carbonates (Fig. 8(6)). Group $\mathrm{K}$ - and $\mathrm{Cl}$ rich which formed during aging of flaming pine smoke in a chamber study (Popovicheva et al., 2015c) is not observed in fresh-emitted peat smoke, likely because in the smoldering phase the increase in the abundance of $\mathrm{K}, \mathrm{Cl}$, and $\mathrm{S}$ in smoke particles is not prominent.

\section{Ambient Aerosols in a City Affected by Peat Burning $P M_{10}$ Evolution and Aerosol Composition}

Large-scale peat fires were identified as a source of the smoke plume exerting a significant impact on air quality in downwind areas of a large city (Engling et al., 2014). Likewise, comprehensive physico-chemical characterization of aerosol particles during large-scale peat and forest fires around Moscow megacity showed massive impact of biomass burning on composition and structure of urban aerosols (Popovicheva et al., 2014).

Evolution of $\mathrm{PM}_{10}$ mass concentrations at a site in the south-western part of Moscow city measured from 31 August to 18 September is shown in Fig. 9. Daily (24 h) $\mathrm{PM}_{10}$ mass concentrations were on average $30 \pm 18 \mu \mathrm{g} \mathrm{m}^{-3}$ and ranged from 21 to $97 \mu \mathrm{g} \mathrm{m}^{-3}$. They exceeded the WHO (World Health Organization) $24 \mathrm{~h}$ standard guideline value of $50 \mu \mathrm{g} \mathrm{m}^{-3}$ on two of the nineteen measurement days, indicating that the PM level was highly impacted by smoke pollution during that time. However, even higher values $\left(1.7 \mathrm{mg} \mathrm{m}^{-3}\right)$ were observed during the extreme smoke event of August 2010 (Gorchakov et al., 2011).

According to the air mass residence time, the regions of the aerosol origin can be categorized into fire-related areas north and north-west of Moscow city and others where fires were not detected at that time. Analysis of $\mathrm{PM}_{10}$ evolution (Fig. 9) shows that the elevated concentrations at the site in the south-western part of Moscow city from 31 
1)

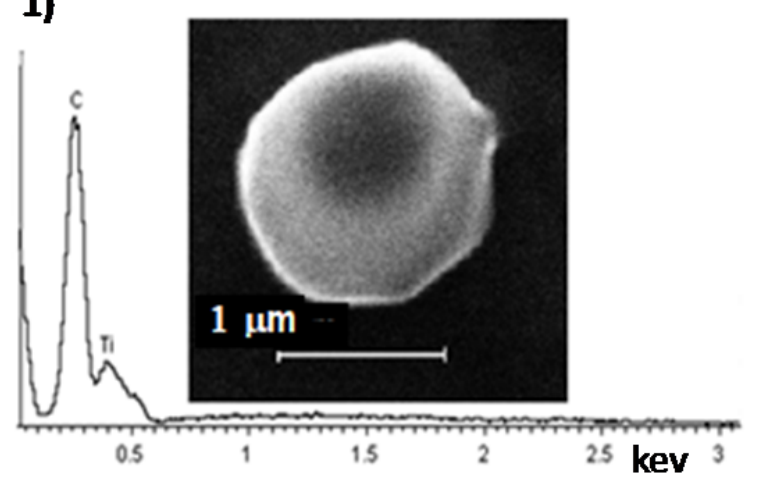

2)

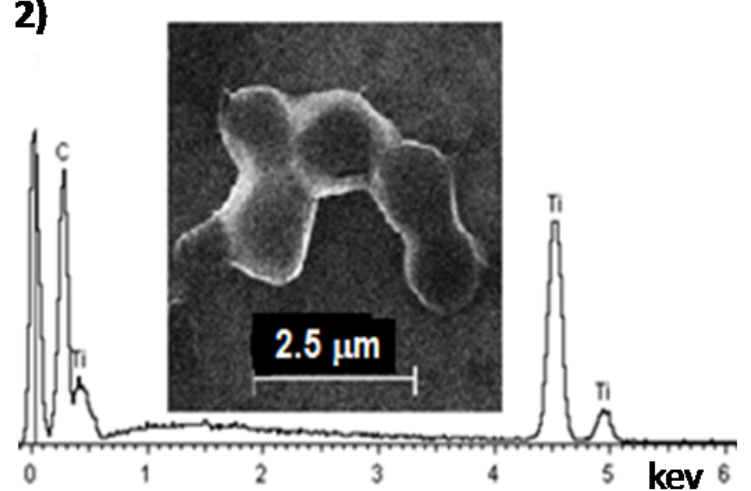

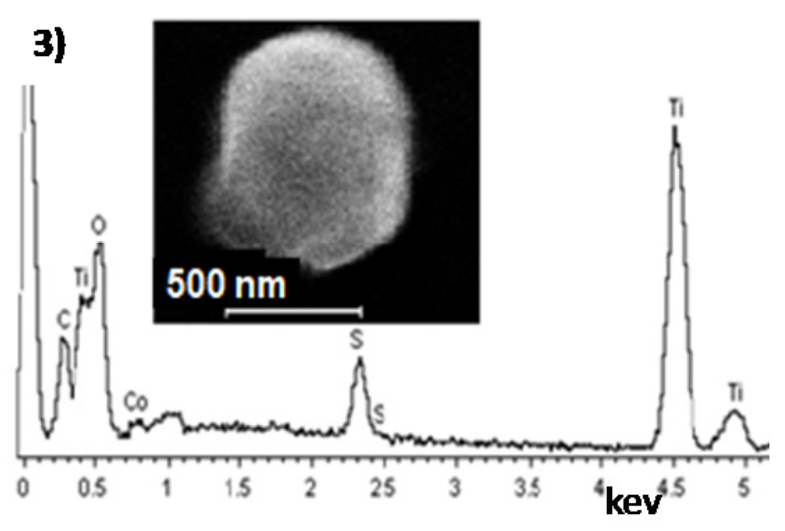

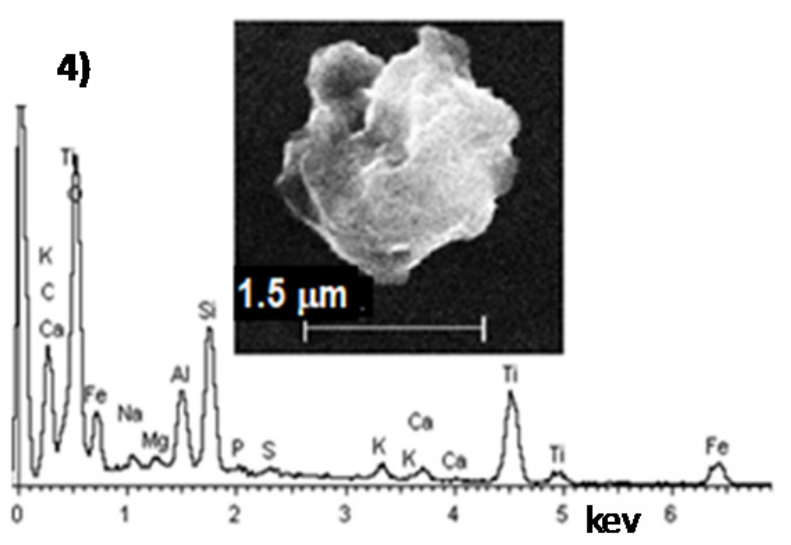

5)

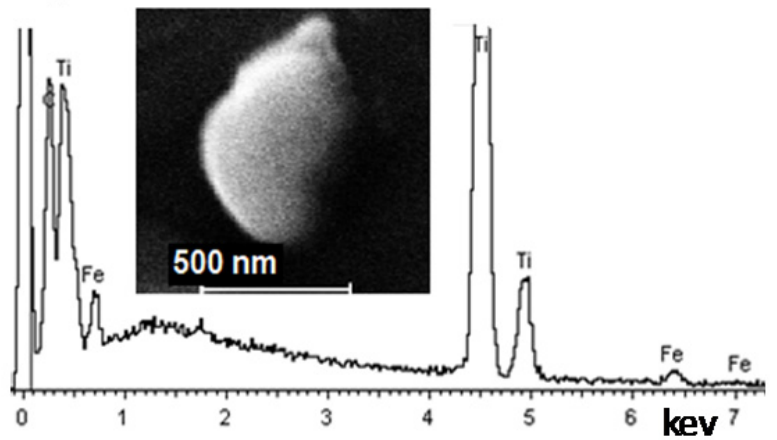

6)

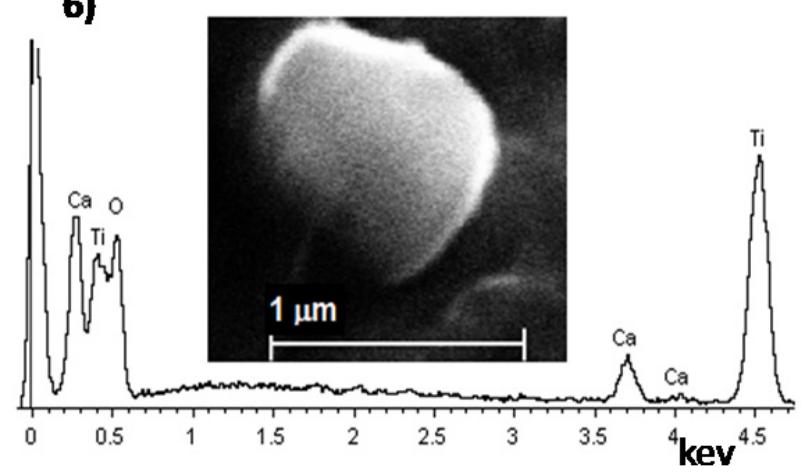

Fig. 8. Representative particle EDX spectra and micrographs in Group Organic of (1) tar balls and (2) tar ball agglomerates of mainly $\mathrm{C}$ and $\mathrm{O}$, and (3) S-containing tar balls; in Group Si-rich of (4) aluminosilicates with Fe, Mg, K, and Ca inclusions; in Group Fe-rich of (5) iron oxides; in Group Ca-rich of (6) calcium oxides/carbonates. Ti is a substrate artifact.

July to 3 August and from 11 to 18 August were related to the peat bog fire plume advected from the Tver and Moscow regions (Fig. 10). During those days the major fractions of aerosols, such as OC, EC, and ions, correlated well with $\mathrm{PM}_{10}$ mass evolution (Fig. 9), showing similar patterns to those observed during a recent study for intensive smokerelated periods (Popovicheva et al., 2016a).

While in urban environments OC may be comparable to EC dominated by traffic and other fossil fuel combustion (Samara et al., 2014), elevated OC/EC ratios (7.18 \pm 0.2$)$ were observed in urban areas during a Siberian forest fire episode (Jung et al., 2016). OC/EC ratios increased up to 8.3 in a megacity due to long-range transport of smoke from wildfires in the European part of Russia (Diapouli et al., 2014). In Moscow city during periods without fire in August 2011 the OC/EC ratio was found to be 9.9 and it increased up to 27.4 during the extreme smoke event (Popovicheva et al., 2014). In our study, along with increased $\mathrm{PM}_{10}$ concentrations, $\mathrm{OC} / \mathrm{EC}$ shows the maximum values on 4 and 12-13 August (up to 7; Table 1), affected by air mass transport from fire-related regions (Fig. 10), in comparison with minimum values of 3 during clean days (from 7 to 10 August; Fig. 11(a)).

Aerosol particles produced by biomass combustion, including wood and grass burning, and by motor vehicles are distinguished by different wavelength $(\lambda)$ dependences 


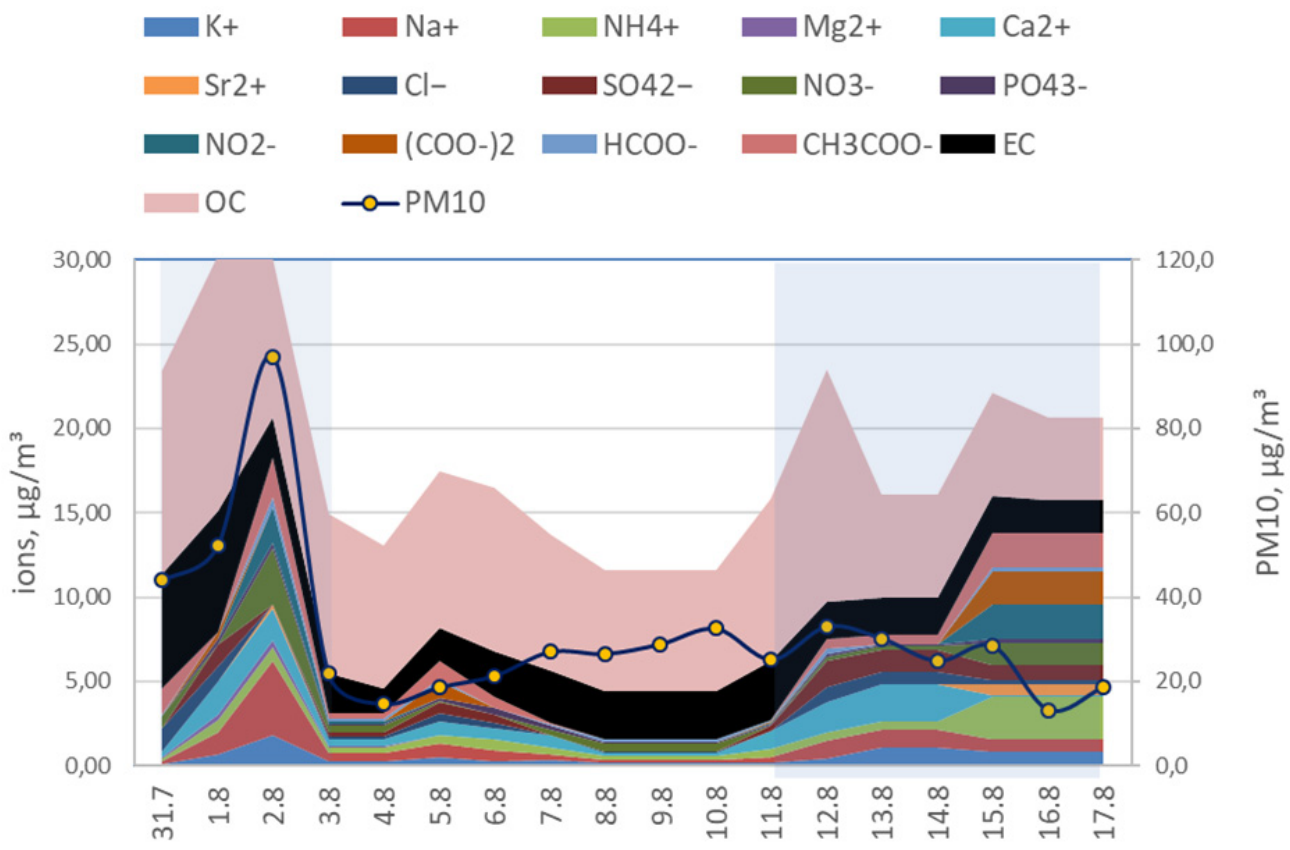

Fig. 9. Timeline of ambient $\mathrm{PM}_{10}$, OC, EC, organic, and inorganic ion concentrations at the site in the south-west of Moscow city. Episodes of air mass transport from fire-related regions north and north-west of Moscow city are indicated by the shaded areas.

in light absorption. BC produced by high-temperature combustion of fossil fuel sources fits within the Rayleigh scattering regime for near-visible wavelengths with a theoretical $\lambda^{-1}$ relationship (Kirchstetter et al., 2004). Weak spectral dependence of attenuation with AAE around 1.0 was observed for diesel soot and urban aerosols (Kirchstetter et al., 2004; Popovicheva et al., 2017b) due to dominant BC derived from high-temperature combustion of fossil fuels. Elevated light absorption with AAE up to 1.3 in comparison with 0.68 is observed for days affected by peat bog plumes (Fig. 10), with maximum values on 4 August and 13-14 August (Fig. 11(a)), well in accordance with increased OC/EC ratios and $\mathrm{PM}_{10}$ mass concentrations (Fig. 9), respectively.

An average levoglucosan concentration of $30 \mathrm{ng} \mathrm{m}^{-3}$ was measured in Moscow city during the period from 5 to 16 August 2011, when no fires were observed around the megacity (Popovicheva et al., 2014). In this study, during the same season (August 2014), we observe an average Lev concentration of $72 \pm 26 \mathrm{ng} \mathrm{m}^{-3}$, ranging from 12 to $102 \mathrm{ng} \mathrm{m}^{-3}$ (Fig. 11(b)). The Lev levels were double of those in August 2011, yet still less than during the extreme smoke in August 2010, when the average Lev concentration was two orders of magnitude higher compared to non-episode periods. Elevated values of Lev coincide with the days of highest $\mathrm{PM}_{10}$ and $\mathrm{OC}$ concentrations (Fig. 9) and show the maximum of $108 \mathrm{ng} \mathrm{m}^{-3}$ on 9 and 10 August when air masses were directly transported from the Tver region, where open fires were detected (Fig. 10). Thus, levoglucosan serves as a suitable molecular marker for peat bog smoldering burns. The Lev/OC ratio in Moscow increased from 0.1 to $1.7 \%$, also indicating the impact of peat burning on ambient aerosols.

The mannosan concentration varied from below detection limits to $21 \mathrm{ng} \mathrm{m}^{-3}$ throughout the sampling period. The Lev/Man ratio was 7 on average, i.e., in the range of diagnostic marker ratios representative of peat smoke with possible contributions from grass smoke as well as coniferous wood burning emissions. Levoglucosan and mannosan showed a remarkably high correlation $\left(\mathrm{R}^{2}=0.99\right)$ between each other, while levoglucosan and galactosan were well correlated as well $\left(\mathrm{R}^{2}=0.86\right)$, indicating their common source material.

Other saccharides, such as arabitol and mannitol, are found at concentrations much lower than those of anhydrosaccharides, in the range from 0.03 to $0.16 \mu \mathrm{g} \mathrm{m}^{-3}$. These compounds are found to comprise only a few percent of total saccharide concentrations in smoke aerosol, indicating their origin being predominantly from natural bioaerosol sources, such as fungal spores and bacteria, whose emission may be suppressed during smoke episodes (Popovicheva et al., 2014).

The abundance of water-soluble organic carbon (WSOC) is often used as an indicator for photochemical oxidation of OC, resulting in SOA formation (Miyazaki et al., 2012). WSOC concentrations measured in $\mathrm{PM}_{10}$ during biomass burning constituted a substantial fraction ( $81 \%$ on average) of OC (Popovicheva et al., 2017b). In our study, analysis of ambient WSOC evolution shows a behavior similar to levoglucosan (Fig. 11(b)), with the elevated concentrations related to the peat bog fire plume from the Tver and Moscow region (Fig. 10). The significance of polar organic species is also reflected in the high fraction of WSOC in OC, approaching $40 \%$ as the maximum WSOC concentration on 9 August.

The ionic aerosol composition at the urban site is characterized by inorganic anions $\left(\mathrm{SO}_{4}{ }^{2-}, \mathrm{Cl}^{-}, \mathrm{NO}_{3}{ }^{-}, \mathrm{NO}_{2}{ }^{-}\right.$, 


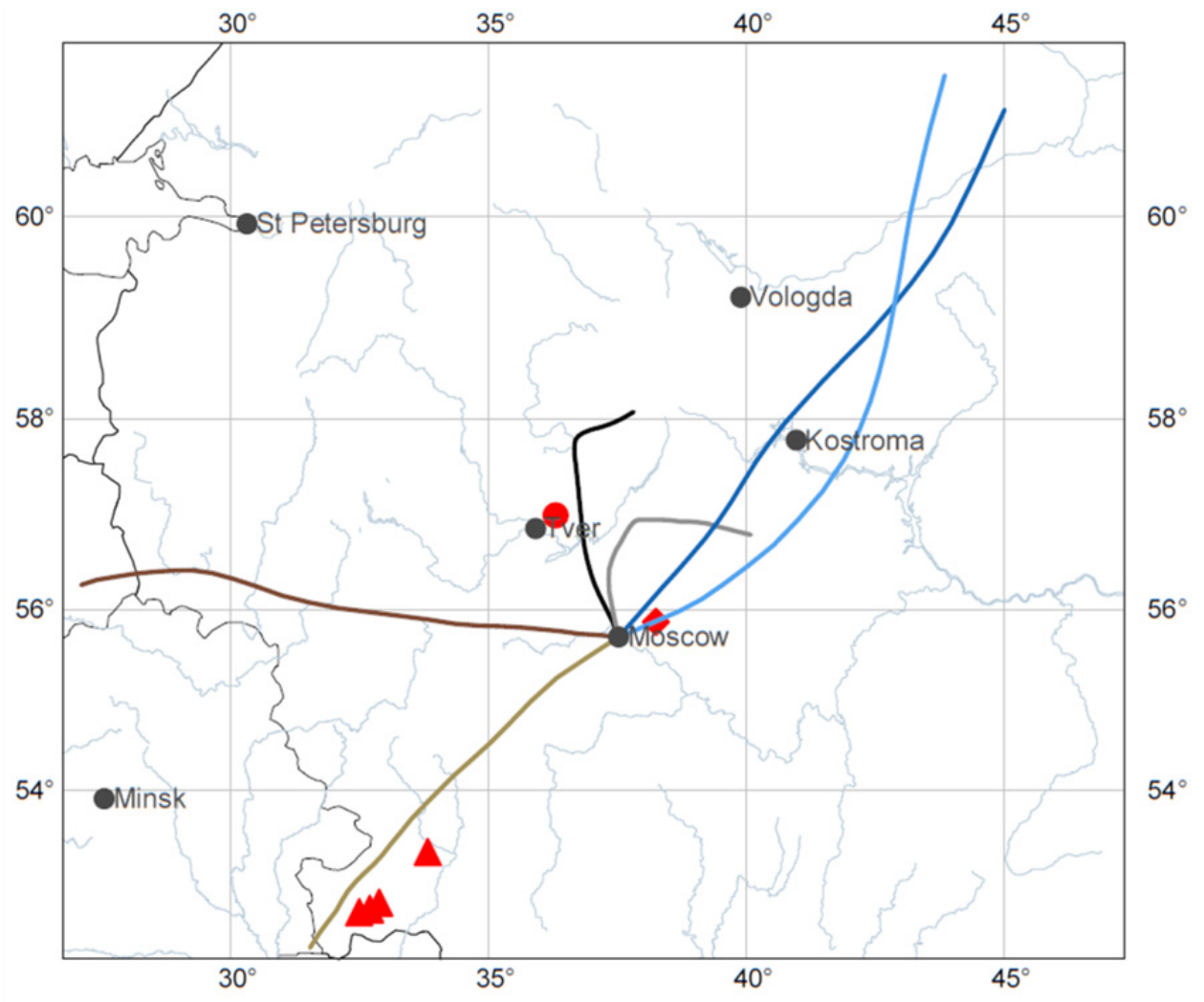

Scale: $1: 13325091$ at Latitude $0^{\circ}$

\begin{tabular}{|l|}
\hline - HYSPLIT 04.08.2014 06:00 \\
- HYSPLIT 04.08.2014 18:00 \\
- HYSPLIT 09.08.2014 06:00 \\
- HYSPLIT 09.08.2014 18:00 \\
- HYSPLIT 13.08.2014 06:00 \\
- HYSPLIT 13.08.2014 18:00 \\
FIRMS 04.08.2014 \\
FIRMS 09.08.2014 \\
FIRMS 13.08.2014
\end{tabular}

Fig. 10. $12 \mathrm{~h}$ air mass back trajectories arriving at the MSU site at $500 \mathrm{~m}$ A.G.L. are indicated as HYSPLIT in different colors for the individual arrival times. Fire hot spots obtained from FIRMS are related to specific trajectories.

$\left.\mathrm{PO}_{4}{ }^{3-}\right)$, cations $\left(\mathrm{Na}^{+}, \mathrm{NH}_{4}^{+}, \mathrm{K}^{+}, \mathrm{Mg}^{2+}, \mathrm{Ca}^{2+}, \mathrm{Sr}^{2+}\right)$ as well as organic ions $\left(\mathrm{HCOO}^{-}, \mathrm{CH}_{3} \mathrm{COO}^{-},(\mathrm{COO})_{2}\right)$. Peak ion concentrations were registered on 2 August when $\mathrm{OC}$ and biomass burning markers were at maximum levels as well. They were dominated by sodium, nitrite, nitrate, calcium, and acetate. These ionic species are typical components of biomass smoke aerosols, with calcium mainly derived from uplifting of soil particles during the combustion process (Kavouras et al., 2012). Combined with strong sulfate and ammonium abundance in smoke aerosols, these observations indicate the formation of secondary inorganic species associated with wildfire gaseous emissions and their transformation during aging of smoke aerosol. Peak ion concentrations were registered on 2 August, when OC and biomass burning markers were at maximum levels. $\mathrm{Sr}^{2+}$ was found only on those days indicating the origin from peat bog fires.

The concentration of $\mathrm{K}^{+}$ion in Moscow ambient aerosols during August 2010 was on average $1.1 \mu^{-3} \mathrm{~m}^{-3}$ which is an order of magnitude higher than values observed one year later (Popovicheva et al., 2014). An important finding was the good correlation of $\mathrm{K}^{+}$with levoglucosan during smoke events (Cheng et al., 2013). We observe $\mathrm{K}^{+}$concentrations ranging from $200 \mathrm{ng} \mathrm{m}^{-3}$ to $1.7 \mu \mathrm{g} \mathrm{m}^{-3}$, with elevated values corresponding to the highest $\mathrm{OC}$ and $\mathrm{PM}_{10}$ concentrations (Fig. 11(b)). The relationship between $\mathrm{K}^{+}$and Lev points to the influence of peat burning smoke on composition of aerosols on 2 and 3 August and after 11 August, while $\mathrm{K}^{+}$ values on 9 and 10 August are found to be much lower. Presumably, a more prominent impact of smoldering than flaming combustion occurred during those days, because high temperature combustion induces higher potassium ion emissions due to more effective vaporization of mineral compounds during biomass burning.

The FTIR absorbance spectra of ambient aerosols demonstrate the functionalities which belong to major classes of organic/inorganic compounds and can be attributed to specific emission sources (Coury and Dillner, 2009). Diesel 

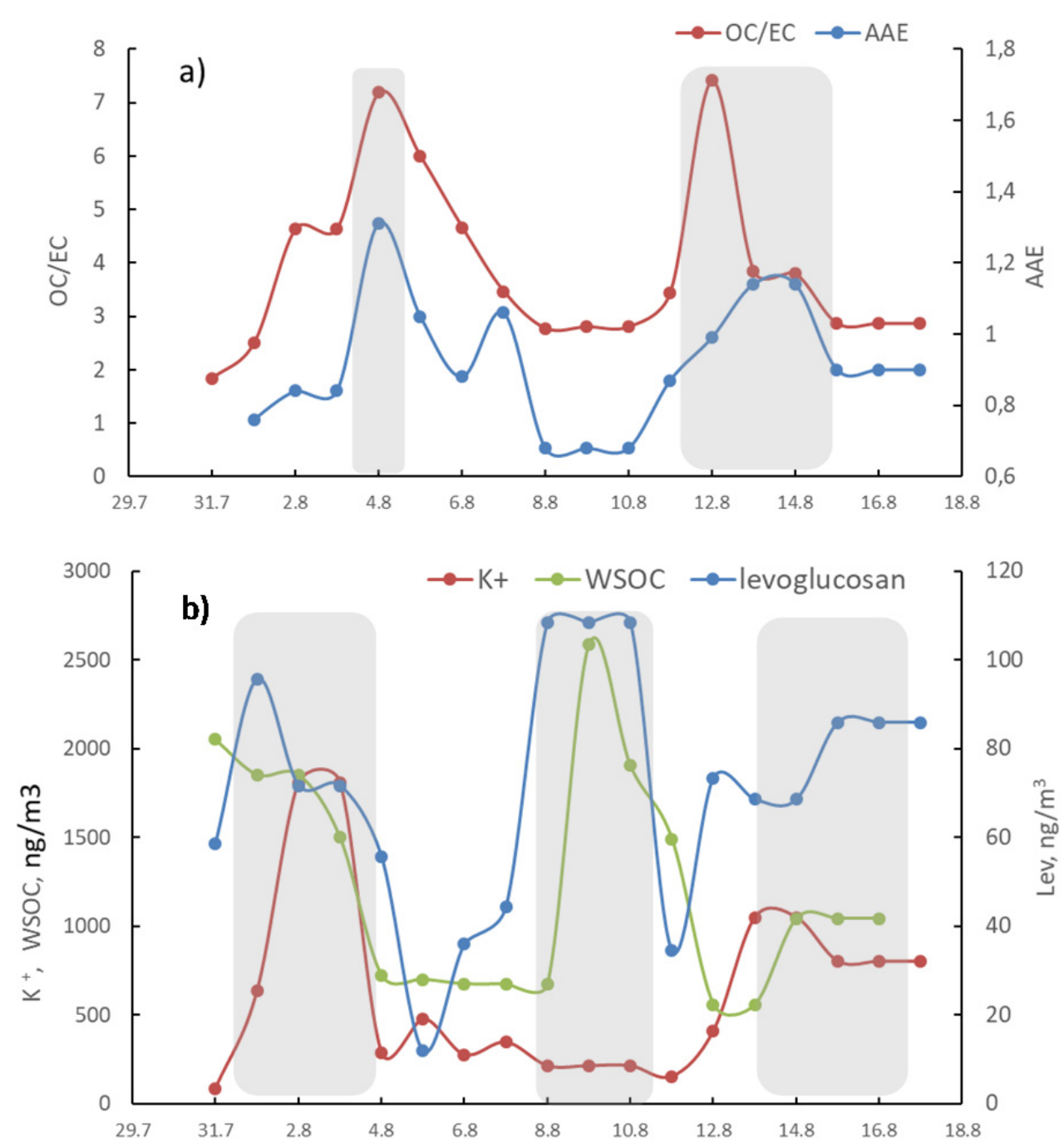

Fig. 11. (a) OC/EC ratios and Absorption Angstrom Exponent (AAE), and (b) organic molecular marker for biomass burning (levoglucosan), water-soluble organic carbon (WSOC), and ionic marker $\left(\mathrm{K}^{+}\right)$concentrations during the sampling period at the MSU site. Episodes of air mass transport from fire-related regions north and north-west of Moscow city are indicated by shaded areas.

soot mainly consists of polycyclic aromatic hydrocarbons, nitro, and carbonyl functionalities (Tapia et al., 2017). The abundance of aliphatic, aromatic, carboxyl, carbonyl, hydroxyl and nitro functional groups depends on the diesel-engine-working regime (Popovicheva et al., 2015b, 2017a). The functionalities of traffic emissions in a large city demonstrate a prominent pattern of aromatic $\mathrm{C}=\mathrm{C}$ and aliphatic C-C-H at $1596 \mathrm{~cm}^{-1}$ and $2922-2850 \mathrm{~cm}^{-1}$, respectively, with carboxyl $\left(1654 \mathrm{~cm}^{-1}\right)$ and carbonyl $\mathrm{C}=\mathrm{O}$ $\left(1700 \mathrm{~cm}^{-1}\right)$ groups (Popovicheva et al., 2017b). Acid and non-acid carbonyl absorbance at 1716 and $1735 \mathrm{~cm}^{-1}$ was much more prominent during extreme smoke events, indicating photochemical oxidation and SOA formation in Moscow megacity (Popovicheva et al., 2014).

FTIR spectra of ambient aerosols in this study are presented in Fig. 4(c). Analyses of the absorbance features shows that they can be grouped according to similar bands demonstrating the identical composition of aerosols collected on different days. On 31 July to 1 August and
12-15 August, when increased $\mathrm{PM}_{10}$, OC, EC, and ion mass concentrations were observed, acid $\left(1700 \mathrm{~cm}^{-1}\right)$ and non-acid $\left(1745,1768 \mathrm{~cm}^{-1}\right) \mathrm{C}=\mathrm{O}$ in acids, esters, lactone, and anhydrates, $\mathrm{C}=\mathrm{C}$ in aromatics $\left(1606 \mathrm{~cm}^{-1}\right), \mathrm{N}-\mathrm{H}$ in amines overlapping with alkenyl $\mathrm{C}=\mathrm{C}$ in alkenes (1635, $\left.1623 \mathrm{~cm}^{-1}\right)$, organic $-\mathrm{NO}_{2}\left(1512,1492 \mathrm{~cm}^{-1}\right)$ in nitro compounds, and $\mathrm{NO}_{3}{ }^{-}$in nitrates $\left(1368,1341 \mathrm{~cm}^{-1}\right)$ are the most prominent functional groups. A distinct carbonyl absorption band in aerosols may suggest the formation of SOA in smoke plumes through high dicarboxylic acid concentrations (Agarwal et al., 2010). Other bands are related to characteristics of peat burning with impact of grass smoldering (Fig. 4(a)), indicating the impact of peat bog smoke on the aerosol chemical composition.

In contrast, the spectra of non-fire related days, on 5-7 August, demonstrate significantly different patterns of dominant aromatic $\mathrm{C}=\mathrm{C}\left(1606,1435 \mathrm{~cm}^{-1}\right)$ and slightly prominent $\mathrm{C}-\mathrm{C}-\mathrm{H}\left(2916 \mathrm{~cm}^{-1}\right)$ groups, characteristic of traffic emissions, with carbonates $\left(\mathrm{CO}_{3}^{-}\right)$and nitrates $\left(\mathrm{NO}_{3}{ }^{-}\right)$ 
at 1430 and $1341 \mathrm{~cm}^{-1}$, respectively. Similar composition was observed for daily ambient aerosols collected in Moscow in August 2011, with weak aliphatic absorbance in comparison to C-O groups $\left(1178,1064 \mathrm{~cm}^{-1}\right)$ and complete absence of carbonyl bands (Popovicheva et al., 2014).

It is interesting to note that during days of maximum levoglucosan concentrations (8-10 August; Fig. 11(b)), the band of acid and non-acid carbonyls $\left(1745 \mathrm{~cm}^{-1}\right)$ appeared to be the widest and more prominent compared to other days, thus indicating the photochemical oxidation having occurred during peat burning plume transport to the city. Along with the carbonyl formation during peat fires, we should note the transformation of aerosol surface functionalities leading to an increase in hydrophilic groups, in agreement with the increase of polar WSOC compounds, which may significantly change the particle hygroscopicity (Popovicheva et al., 2009), leading to an increase of CCN activity. The spectra on 4 and 11 August are found to be essentially identical, when maximum values of $\mathrm{OC} / \mathrm{EC}$ ratios and $\mathrm{AAE}$ were identified (Fig. 11(a)). These spectra are dominated by absorption of nitrogen-containing $\mathrm{N}-\mathrm{H}$ and $-\mathrm{NO}_{2}$ compounds which are probably related to $\mathrm{BrC}$.

\section{CONCLUSIONS}

Peatlands, with the largest reserves found in Russia, are important source regions of biomass smoke. These natural areas are subject to frequent burning, which is often associated with large-scale forest fires. The chemical composition and microstructure of particulate matter emissions from long-lasting peat bog smoldering in the European part of Russia, the Tver region, is reported here for the first time. Organic carbon dominates peat burning emissions, with OC/EC ratios varying from 10 to 20 . The amines, aromatic nitro compounds, and nitrates of grass smoldering accompany the organic aliphatics, aromatics, carbonyls, and carboxylates of underground smoke. The contribution from oxygenated water-soluble organic carbon (WSOC) is augmented by ammonium, potassium, and sodium sulfates as well as nitrates, silicates, and carbonates from grass smoldering, thus inducing SOA and $\mathrm{CCN}$ formation. Levoglucosan, a biomass burning molecular marker, is found to contribute up to $9 \%$ of the OC. Whereas potassium ions comprise only a small fraction of the total ions (up to $7 \%$ ), sulfates are the most abundant ionic species in smoke both inside and above the grass, consistent with gaseous emissions and gas-to-particle reactions of $\mathrm{SO}_{2}$ aboveground.

The optical properties of peat burning identified for the near-ultraviolet to the near-infrared spectral region include a high AAE of 4.1 and a large fraction of light-absorbing, i.e., brown, carbon $(\mathrm{BrC})$, indicating that AAE can serve as a source-specific optical marker of peat bog smoldering and significant amounts of light-absorbing carbon. Analyzing individual particles reveals that a high abundance of roughly spherical tar balls can be utilized as a micromarker of peat burning; furthermore, to accurately estimate effects on the earth's radiation budget, effectively utilize remote sensing, and understand UV light absorption patterns in the troposphere, the optical properties of these tar balls must be included in radiative forcing models (Chakrabarty et al., 2010).

Samples collected from an urban site in Moscow during a period of peat bog fires illustrated the regional influence of peat burning emissions, which affected $\mathrm{PM}_{10}$ mass, OC, and ion concentrations in the city. Elevated values exhibited by the diagnostic ratios (e.g., OC/EC), optical (AAE) and chemical (levoglucosan) markers, and WSOC were well correlated with episodes of air mass transport from peat bog fire regions. On these days, the absorption spectra displayed bands similar to the spectra of peat bog smoke particles, which exerted considerable influence on the aerosol chemistry in downwind areas. Thus, comprehensively characterizing aerosol emissions from the long-lasting smoldering of boreal peatlands reveals specific chemical features of regional biomass burning emissions and demonstrates the large impact of wildfires on the air quality in megacities, harming both human and environmental health.

\section{ACKNOWLEDGMENTS}

This work was financially supported by a project of the Russian Geographical Society (No. 11/2018-P). The authors are grateful to Dr. E. Kireeva for measurements of the FTIR spectra and to A. Ivanov for HYSPLIT calculations.

\section{REFERENCES}

Agarwal, S., Aggarwal, S.G., Okuzawa, K. and Kawamura, K. (2010). Size distributions of dicarboxylic acids, ketoacids, $\alpha$-dicarbonyls, sugars, WSOC, OC, EC and inorganic ions in atmospheric particles over Northern Japan: implication for long-range transport of Siberian biomass burning and East Asian polluted aerosols. Atmos. Chem. Phys. 10: 5839-5858.

Alves, C., Gonçalves, C., Evtyugina, M., Pio, C., Mirante, F. and Puxbaum, H. (2010). Particulate organic compounds emitted from experimental wildland fires in a Mediterranean ecosystem. Atmos. Environ. 44: 27502759.

Alves, C.A., Vicente, E.D., Rocha, S. and Vicente, A.M. (2017). Organic tracers in aerosols from the residential combustion of pellets and agro-fuels. Air Qual. Atmos. Health 10: 37-45.

Andreae, M.O. (1983). Soot carbon and excess fine potassium: Long-range transport of combustion-derived aerosols. Science 220: 1148-1151.

Baltensperger, U., Dommen, J., Alfarra, M.R., Duplissy, J., Gaeggeler, K., Metzger, A., Facchini, M.C., Decesari, S., Finessi, E. and Reinnig, C. (2008). Combined determination of the chemical composition and of health effects of secondary organic aerosols: The POLYSOA project. J. Aerosol Med. Pulm. Drug Delivery 21: 145154.

Barriopedro, D., Fischer, E.M., Luterbacher, J., Trigo, R.M. and García-Herrera, R. (2011). he hot summer of 2010: Redrawing the temperature record map of Europe. Science 332: 220-224. 
Birch, M.E. and Cary, R.A. (1996). Elemental carbonbased method for monitoring occupational exposure to particulate diesel exhaust. Aerosol Sci. Technol. 25: 221-241.

Chakrabarty, R., Moosmüller, H., Chen, L.W., Lewis, K., Arnott, W., Mazzoleni, C., Dubey, M., Wold, C., Hao, W. and Kreidenweis, S. (2010). Brown carbon in tar balls from smoldering biomass combustion. Atmos. Chem. Phys. 10: 6363-6370.

Chakrabarty, R.K., Moosmüller, H., Garro, M.A., Arnott, W.P., Walker, J., Susott, R.A., Babbitt, R.E., Wold, C.E., Lincoln, E.N. and Hao, W.M. (2006). Emissions from the laboratory combustion of wildland fuels: Particle morphology and size. J. Geophys. Res. 111: D07204.

Chakrabarty, R.K., Gyawali, M., Yatavelli, R.L., Pandey, A., Watts, A.C., Knue, J., Chen, L.W.A., Pattison, R.R., Tsibart, A. and Samburova, V. (2016). Brown carbon aerosols from burning of boreal peatlands: Microphysical properties, emission factors, and implications for direct radiative forcing. Atmos. Chem. Phys. 16: 3033-3040.

Chen, Y. and Bond, T. (2010). Light absorption by organic carbon from wood combustion. Atmos. Chem. Phys. 10: 1773-1787.

Cheng, Y., Engling, G., He, K.B., Duan, F.K., Ma, Y.L., Du, Z.Y., Liu, J.M., Zheng, M. and Weber, R.J. (2013). Biomass burning contribution to Beijing aerosol. Atmos. Chem. Phys. 13: 7765-7781.

Chubarova, N., Gorbarenko, E. and Shilovtseva, O. (2011). Aerosol and radiation characteristics of the atmosphere during forest and peat fires in 1972, 2002, and 2010 in the region of Moscow. Izv. Atmos. Oceanic Phys. 47: 729-738.

Coury, C. and Dillner, A.M. (2009). ATR-FTIR characterization of organic functional groups and inorganic ions in ambient aerosols at a rural site. Atmos. Environ. 43: 940-948.

Dare, P., Gifford, J., Hooper, R., Clemens, A., Damiano, L., Gong, D. and Matheson, T. (2001). Combustion performance of biomass residue and purpose grown species. Biomass Bioenergy 21: 277-287.

Diapouli, E., Popovicheva, O., Kistler, M., Vratolis, S., Persiantseva, N., Timofeev, M., Kasper-Giebl, A. and Eleftheriadis, K. (2014). Physicochemical characterization of aged biomass burning aerosol after long-range transport to Greece from large scale wildfires in Russia and surrounding regions, Summer 2010. Atmos. Environ. 96: 393-404.

Ding, X., Wang, X., Xie, Z., Zhang, Z. and Sun, L. (2013). Impacts of Siberian biomass burning on organic aerosols over the North Pacific Ocean and the Arctic: Primary and secondary organic tracers. Environ. Sci. Technol. 47: 3149-3157.

Engling, G., Carrico, C.M., Kreidenweis, S.M., Collett, J.L., Jr., Day, D.E., Malm, W.C., Hao, W.M., Lincoln, E., Iinuma, Y. and Herrmann, H. (2006a). Determination of levoglucosan in biomass combustion aerosol by highperformance anion-exchange chromatography with pulsed amperometric detection. Atmos. Environ. 40: 299-311.

Engling, G., Herckes, P., Kreidenweis, S.M., Malm, W.C. and Collett, Jr, J.L. (2006b). Composition of the fine organic aerosol in Yosemite National Park during the 2002 Yosemite Aerosol Characterization Study. Atmos. Environ. 40: 2959-2972.

Engling, G., He, J., Betha, R. and Balasubramanian, R. (2014). Assessing the regional impact of Indonesian biomass burning emissions based on organic molecular tracers and chemical mass balance modeling. Atmos. Chem. Phys. 14: 8043-8054.

Fine, P.M., Cass, G.R. and Simoneit, B.R. (2004). Chemical characterization of fine particle emissions from the fireplace combustion of wood types grown in the Midwestern and Western United States. Environ. Eng. Sci. 21: 387-409.

Fujii, Y., Kawamoto, H., Tohno, S., Oda, M., Iriana, W. and Lestari, P. (2015). Characteristics of carbonaceous aerosols emitted from peatland fire in Riau, Sumatra, Indonesia (2): Identification of organic compounds. Atmos. Environ. 110: 1-7.

Gao, S., Hegg, D.A., Hobbs, P.V., Kirchstetter, T.W., Magi, B.I. and Sadilek, M. (2003). Water-soluble organic components in aerosols associated with savanna fires in southern Africa: Identification, evolution, and distribution. J. Geophys. Res. 108: 8491.

Gaveau, D.L.A., Salim, M.A., Hergoualc'h, K., Locatelli, B., Sloan, S., Wooster, M., Marlier, M.E., Molidena, E., Yaen, H., DeFries, R., Verchot, L., Murdiyarso, D., Nasi, R., Holmgren, P. and Sheil, D. (2014). Major atmospheric emissions from peat fires in Southeast Asia during nondrought years: Evidence from the 2013 Sumatran fires. Sci. Rep. 4: 6112.

George, I.J., Black, R.R., Geron, C.D., Aurell, J., Hays, M.D., Preston, W.T. and Gullett, B.K. (2016). Volatile and semivolatile organic compounds in laboratory peat fire emissions. Atmos. Environ. 132: 163-170.

Gorchakov, G.I., Sviridenkov, M.A., Semoutnikova, E.G., Chubarova, N.Y., Holben, B.N., Smirnov, A.V., Emilenko, A.S., Isakov, A.A., Kopeikin, V.M., Karpov, A.V., Lezina, E.A. and Zadorozhnaya, O.S. (2011). Optical and microphysical parameters of the aerosol in the smoky atmosphere of the Moscow region in 2010. Dokl. Earth Sci. 437: 513-517.

Gras, J., Jensen, J., Okada, K., Ikegami, M., Zaizen, Y. and Makino, Y. (1999). Some optical properties of smoke aerosol in Indonesia and tropical Australia. Geophys. Res. Lett. 26: 1393-1396.

Hadden, R.M., Rein, G. and Belcher, C.M. (2013). Study of the competing chemical reactions in the initiation and spread of smouldering combustion in peat. Proc. Combust. Inst. 34: 2547-2553.

Hand, J.L., Malm, W.C., Laskin, A., Day, D., Lee, T., Wang, C., Carrico, C., Carrillo, J., Cowin, J.P., Collett, J. and Iedema, M.J. (2005). Optical, physical, and chemical properties of tar balls observed during the Yosemite Aerosol Characterization Study. J. Geophys. Res. 110: D21210.

Ikegami, M., Okada, K., Zaizen, Y., Makino, Y., Jensen, J.B., Gras, J.L. and Harjanto, H. (2001). Very high weight ratios of $\mathrm{S} / \mathrm{K}$ in individual haze particles over 
Kalimantan during the 1997 Indonesian forest fires. Atmos. Environ. 35: 4237-4243.

Jung, J., Lyu, Y., Lee, M., Hwang, T., Lee, S. and Oh, S. (2016). Impact of Siberian forest fires on the atmosphere over the Korean Peninsula during summer 2014. Atmos. Chem. Phys. 16: 6757-6770.

Kalogridis, A.C., Popovicheva, O.B., Engling, G., Diapouli, E., Kawamura, K., Tachibana, E., Ono, K., Kozlov, V.S. and Eleftheriadis, K. (2018). Smoke aerosol chemistry and aging of Siberian biomass burning emissions in a large aerosol chamber. Atmos. Environ. 185: 15-28.

Kavouras, I.G., Nikolich, G., Etyemezian, V., DuBois, D.W., King, J. and Shafer, D. (2012). In situ observations of soil minerals and organic matter in the early phases of prescribed fires. J. Geophys. Res. 117: D12313.

Kirchstetter, T. and Thatcher, T. (2012). Contribution of organic carbon to wood smoke particulate matter absorption of solar radiation. Atmos. Chem. Phys. 12: 6067-6072.

Kirchstetter, T.W., Novakov, T. and Hobbs, P.V. (2004). Evidence that the spectral dependence of light absorption by aerosols is affected by organic carbon. J. Geophys. Res. 109: D21208.

Kireeva, E.D., Popovicheva, O.B., Persiantseva, N.M., Timofeyev, M.A. and Shonija, N.K. (2009). Fractionation analysis of transport engine-generated soot particles with respect to hygroscopicity. J. Atmos. Chem. 64: 129-147.

Koehler, K.A., DeMott, P.J., Kreidenweis, S.M., Popovicheva, O.B., Petters, M.D., Carrico, C.M., Kireeva, E.D., Khokhlova, T.D. and Shonija, N.K. (2009). Cloud condensation nuclei and ice nucleation activity of hydrophobic and hydrophilic soot particles. Phys. Chem. Chem. Phys. 11: 7906-7920.

Kuznetsov, B., Rakhmanova, T., Popovicheva, O. and Shonija, N. (2003). Water adsorption and energetic properties of spark discharge soot: Specific features of hydrophilicity. J. Aerosol Sci. 34: 1465-1479.

Langmann, B. and Graf, H. (2003). Indonesian smoke aerosols from peat fires and the contribution from volcanic sulfur emissions. Geophys. Res. Lett. 30: 1547.

Langmann, B. and Heil, A. (2004). Release and dispersion of vegetation and peat fire emissions in the atmosphere over Indonesia 1997/1998. Atmos. Chem. Phys. 4: 21452160.

Levine, J.S. (1999). The 1997 fires in Kalimantan and Sumatra, Indonesia: Gaseous and particulate emissions. Geophys. Res. Lett. 26: 815-818.

Liu, X., Van Espen, P., Adams, F., Cafmeyer, J. and Maenhaut, W. (2000). Biomass burning in southern Africa: Individual particle characterization of atmospheric aerosols and savanna fire samples. J. Atmos. Chem. 36: 135-155.

Maria, S.F., Russell, L.M., Turpin, B.J. and Porcja, R.J. (2002). FTIR measurements of functional groups and organic mass in aerosol samples over the Caribbean. Atmos. Environ. 36: 5185-5196.

Mikhailov, E.F., Mironova, S., Mironov, G., Vlasenko, S., Panov, A., Chi, X., Walter, D., Carbone, S., Artaxo, P. and
Heimann, M. (2017). Long-term measurements (20102014) of carbonaceous aerosol and carbon monoxide at the Zotino Tall Tower Observatory (ZOTTO) in central Siberia. Atmos. Chem. Phys. 17: 14365-14392.

Mircea, M., Facchini, M., Decesari, S., Cavalli, F., Emblico, L., Fuzzi, S., Vestin, A., Rissler, J., Swietlicki, E. and Frank, G. (2005). Importance of the organic aerosol fraction for modeling aerosol hygroscopic growth and activation: A case study in the Amazon Basin. Atmos. Chem. Phys. 5: 3111-3126.

Miyazaki, Y., Jung, J., Fu, P., Mizoguchi, Y., Yamanoi, K. and Kawamura, K. (2012). Evidence of formation of submicrometer water-soluble organic aerosols at a deciduous forest site in northern Japan in summer. $J$. Geophys. Res. 117: D19213.

Ohlemiller, T.J., Kashiwagi, T. and Werner, K. (1985). Products of wood gasification, National Bureau of Standards, Gaithersburg, MD, USA.

Osán, J., Alföldy, B., Török, S. and Van Grieken, R. (2002). Characterisation of wood combustion particles using electron probe microanalysis. Atmos. Environ. 36: 2207-2214.

Petters, M.D., Carrico, C.M., Kreidenweis, S.M., Prenni, A.J., DeMott, P.J., Collett, J.L. and Moosmuller, H. (2009). Cloud condensation nucleation activity of biomass burning aerosol. J. Geophys. Res. 114: D22205.

Popovicheva, O., Kireeva, E., Shonija, N. and Khokhlova, T. (2009). Water interaction with laboratory-simulated fossil fuel combustion particles. J. Phys. Chem. A 113: 10503-10511.

Popovicheva, O., Kireeva, E., Persiantseva, N., Timofeev, M., Bladt, H., Ivleva, N.P., Niessner, R. and Moldanová, J. (2012). Microscopic characterization of individual particles from multicomponent ship exhaust. J. Environ. Monit. 14: 3101-3110.

Popovicheva, O., Kistler, M., Kireeva, E., Persiantseva, N., Timofeev, M., Kopeikin, V. and Kasper-Giebl, A. (2014). Physicochemical characterization of smoke aerosol during large-scale wildfires: Extreme event of August 2010 in Moscow. Atmos. Environ. 96: 405-414.

Popovicheva, O., Engling, G., Lin, K.T., Persiantseva, N., Timofeev, M., Kireeva, E., Völk, P., Hubert, A. and Wachtmeister, G. (2015a). Diesel/biofuel exhaust particles from modern internal combustion engines: Microstructure, composition, and hygroscopicity. Fuel 157: 232-239.

Popovicheva, O.B., Kireeva, E.D., Shonija, N.K., VojtisekLom, M. and Schwarz, J. (2015b). FTIR analysis of surface functionalities on particulate matter produced by off-road diesel engines operating on diesel and biofuel. Environ. Sci. Pollut. Res. Int. 22: 4534-4544.

Popovicheva, O.B., Kozlov, V.S., Engling, G., Diapouli, E., Persiantseva, N.M., Timofeev, M., Fan, T.S., Saraga, D. and Eleftheriadis, K. (2015c). Small-scale study of siberian biomass burning: I. Smoke microstructure. Aerosol Air Qual. Res. 15: 117-128.

Popovicheva, O.B., Engling, G., Diapouli, E., Saraga, D., Persiantseva, N.M., Timofeev, M., Kireeva, E.D., Shonija, N.K., Chen, S.H. and Nguyen, D.L. (2016a). Impact of smoke intensity on size-resolved aerosol 
composition and microstructure during the biomass burning season in northwest Vietnam. Aerosol Air Qual. Res. 16: 2635-2654.

Popovicheva, O.B., Kozlov, V.S., Rakhimov, R.F., Shmargunov, V.P., Kireeva, E.D., Persiantseva, N.M., Timofeev, M.A., Engling, G., Elephteriadis, K., Diapouli, L., Panchenko, M.V., Zimmermann, R. and Kreis., J.S. (2016b). Optical-microphysical and physical-chemical characteristics of Siberian biomass burning: Experiments in Aerosol Chamber. Atmos. Oceanic Opt. 29: 492-500.

Popovicheva, O.B., Persiantseva, N.M., Timofeev, M.A., Shonija, N.K. and Kozlov, V.S. (2016c). Small-scale study of siberian biomass burning: II. Smoke hygroscopicity. Aerosol Air Qual. Res. 16: 1558-1568.

Popovicheva, O.B., Irimiea, C., Carpentier, Y., Ortega, I.K., Kireeva, E.D., Shonija, N.K., Schwarz, J., VojtíšekLom, M. and Focsa, C. (2017a). Chemical composition of diesel/biodiesel particulate exhaust by FTIR spectroscopy and mass spectrometry: Impact of fuel and driving cycle. Aerosol Air Qual. Res. 17: 1717-1734.

Popovicheva, O.B., Shonija, N.K., Persiantseva, N., Timofeev, M., Diapouli, E., Eleftheriadis, K., Borgese, L. and Nguyen, X.A. (2017b). Aerosol pollutants during agricultural biomass burning: A case study in $\mathrm{Ba} \mathrm{Vi}$ region in Hanoi, Vietnam. Aerosol Air Qual. Res. 17: 2762-2779.

Pósfai, M., Simonics, R., Li, J., Hobbs, P.V. and Buseck, P.R. (2003). Individual aerosol particles from biomass burning in southern Africa: 1. Compositions and size distributions of carbonaceous particles. J. Geophys. Res. 108.

Reid, J.S., Koppmann, R., Eck, T.F. and Eleuterio, D.P. (2005). A review of biomass burning emissions Part II: intensive physical properties of biomass burning particles. Atmos. Chem. Phys. 5: 799-825.

Samara, C., Voutsa, D., Kouras, A., Eleftheriadis, K., Maggos, T., Saraga, D. and Petrakakis, M. (2014). Organic and elemental carbon associated to $\mathrm{PM}_{10}$ and $\mathrm{PM}_{2.5}$ at urban sites of northern Greece. Environ. Sci. Pollut. Res. Int. 21: 1769-1785.

Schmidl, C., Marr, I.L., Caseiro, A., Kotianová, P., Berner, A., Bauer, H., Kasper-Giebl, A. and Puxbaum, H. (2008). Chemical characterisation of fine particle emissions from wood stove combustion of common woods growing in mid-European Alpine regions Atmos. Environ. 42: 126-141.

See, S.W., Balasubramanian, R. and Wang, W. (2006). A study of the physical, chemical, and optical properties of ambient aerosol particles in Southeast Asia during hazy and nonhazy days. J. Geophys. Res. 111: D10S08.

See, S.W., Balasubramanian, R., Rianawati, E., Karthikeyan, S. and Streets, D.G. (2007). Characterization and source apportionment of particulate matter $\leq 2.5 \mu \mathrm{m}$ in Sumatra, Indonesia, during a recent peat fire episode. Environ. Sci. Technol. 41: 3488-3494.

Shafizadeh, F. and Fu, Y. (1973). Pyrolysis of cellulose. Carbohydr. Res. 29: 113-122.

Shafizadeh, F., Furneaux, R.H., Cochran, T.G., Scholl, J.P. and Sakai, Y. (1979). Production of levoglucosan and glucose from pyrolysis of cellulosic materials. J. Appl. Polym. Sci.c 23: 3525-3539.

Sheng, Y., Smith, L.C., MacDonald, G.M., Kremenetski, K.V., Frey, K.E., Velichko, A.A., Lee, M., Beilman, D.W. and Dubinin, P. (2004). A high-resolution GISbased inventory of the west Siberian peat carbon pool. Global Biogeochem. Cycles 18: GB3004.

Simoneit, B.R.T., Schauer, J.J., Nolte, C.G., Oros, D.R., Elias, V.O., Fraser, M.P., Rogge, W.F. and Cass, G.R. (1999). Levoglucosan, a tracer for cellulose in biomass burning and atmospheric particles. Atmos. Environ. 33: 173-182.

Stein, A., Draxler, R., Rolph, G., Stunder, B., Cohen, M. and Ngan, F. (2015). NOAA's HYSPLIT atmospheric transport and dispersion modeling system. Bull. Am. Meteorol. Soc. 96: 2059-2077.

Steinnes, E., Hvatum, O., Bølviken, B. and Varskog, P. (2005). Atmospheric supply of trace elements studied by peat samples from ombrotrophic bogs. J. Environ. Qual. 34: 192-197.

Stockwell, C.E., Yokelson, R.J., Kreidenweis, S.M., Robinson, A.L., DeMott, P.J., Sullivan, R.C., Reardon, J., Ryan, K.C., Griffith, D.W.T. and Stevens, L. (2014). Trace gas emissions from combustion of peat, crop residue, domestic biofuels, grasses, and other fuels: Configuration and Fourier transform infrared (FTIR) component of the fourth Fire Lab at Missoula Experiment (FLAME-4). Atmos. Chem. Phys. 14: 97279754.

Tapia, A., Salgado, M., Martín, M., Rodríguez-Fernández, J., Rossi, M. and Cabañas, B. (2017). Chemical characterization of diesel and hydrotreated vegetable oil (HVO) soot after reactive gas probing using diffuse reflectance FTIR spectroscopy (DRIFTS). Environ. Sci. Pollut. Res. Int. 24: 7534-7543.

Turetsky, M.R., Benscoter, B., Page, S., Rein, G., Van Der Werf, G.R. and Watts, A. (2015). Global vulnerability of peatlands to fire and carbon loss. Nat. Geosci. 8: 11.

Vassilev, S.V., Baxter, D., Andersen, L.K., Vassileva, C.G. and Morgan, T.J. (2012). An overview of the organic and inorganic phase composition of biomass. Fuel 94 : $1-33$.

Volkova, E.M., Gorelova, S.V. and Musafarov, E.H. (2012). Biomonitpring of anthropogenic pollution of Tula region on the basis of analyses of acculation of heavy metals in Peat Bogs. Natural Science, Izvestia Tula state University, pp. 253-263.

Xu, J.S., Tai, X.H., Betha, R., He, J. and Balasubramanian, R. (2015). omparison of physical and chemical properties of ambient aerosols during the 2009 haze and non-haze periods in Southeast Asia. Environ. Geochem. Health 37: 831-841.

Zaccone, C., Rein, G., D’Orazio, V., Hadden, R.M., Belcher, C.M. and Miano, T.M. (2014). Smouldering fire signatures in peat and their implications for palaeoenvironmental reconstructions. Geochim. Cosmochim. Acta 137: 134146.

Zhang, Z.S., Engling, G., Chan, C.Y., Yang, Y.H., Lin, M., Shi, S., He, J., Li, Y.D. and Wang, X.M. (2013). 
Determination of isoprene-derived secondary organic aerosol tracers (2-methyltetrols) by HPAEC-PAD: Results from size-resolved aerosols in a tropical rainforest. Atmos. Environ. 70: 468-476.
Received for review, August 31, 2018 Revised, November 1, 2018 Accepted, December 27, 2018 